The Cryosphere Discuss., https://doi.org/10.5194/tc-2017-184

Manuscript under review for journal The Cryosphere

Discussion started: 27 September 2017

(c) Author(s) 2017. CC BY 4.0 License.

\title{
Distributed $v s$. semi-distributed simulations of snowpack dynamics in alpine areas: case study in the upper Arve catchment, French Alps, 1989-2015
}

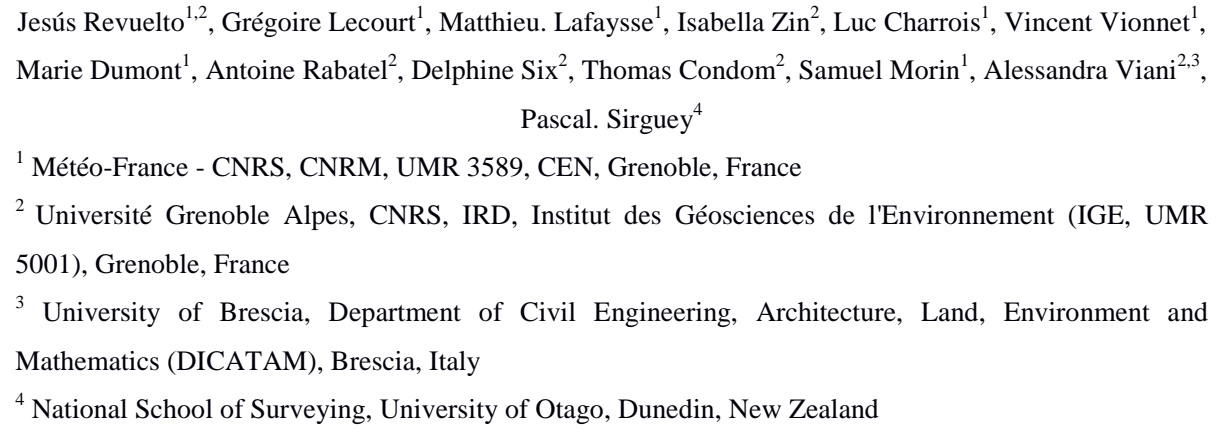

Abstract: We evaluated distributed and semi-distributed modeling approaches to simulating the spatial and temporal evolution of snow and ice over an extended mountain catchment, using the Crocus snowpack model. The distributed approach simulated the snowpack dynamics on a 250-m grid, enabling inclusion of terrain shadowing effects. The semi-distributed approach simulated the snowpack dynamics for discrete topographic classes characterized by elevation range, aspect, and slope. This provided a categorical simulation that was subsequently spatially re-projected over the 250-m grid used for the distributed simulations. The study area (the upper Arve catchment, western Alps, France) is characterized by complex topography, including steep slopes, an extensive glaciated area, and snow cover throughout the year. Simulations were carried out for the period 1989-2015 using the SAFRAN meteorological forcing system. The simulations were compared using four observation datasets including point snow depth measurements, seasonal and annual glacier surface mass balance, snow covered area evolution based on optical satellite sensors, and the annual equilibrium-line altitude of glacier zones, derived from satellite images. The results showed that in both approaches the Crocus snowpack model effectively reproduced the snowpack distribution over the study period. Slightly better results were obtained using the distributed approach because it included the effects of shadows and terrain characteristics.

Key words: snowpack simulation, distributed, semi-distributed, mountain areas, glacierized catchments 
The Cryosphere Discuss., https://doi.org/10.5194/tc-2017-184

Manuscript under review for journal The Cryosphere

Discussion started: 27 September 2017

(c) Author(s) 2017. CC BY 4.0 License.

\section{Introduction}

The dynamics of the accumulation and melting of snow and ice in mountain areas has major effects on the timing and level of discharge from rivers in downstream areas. One-sixth of the Earth's population depends directly on the water supply from snow and ice melt in mountain areas (Barnett et al., 2005). Thus, significant research effort has been applied to the study of snow and ice dynamics in these regions (Egli and Jonas, 2009; Lehning et al., 2011; López-Moreno et al., 2013; McCreight et al., 2012), with particular focus on mountain hydrology (DeBeer and Pomeroy, 2009; López-Moreno and García-Ruiz, 2004; Oreiller et al., 2014; Viviroli et al., 2007). The snowpack dynamics and its spatial extent also control many mountain processes, including soil erosion (Meusburger et al., 2014), plant survival (Wipf et al., 2009), and the glacier surface mass balance (López-Moreno et al., 2016; Réveillet et al., 2017; Sold et al., 2013).

Some of the most dangerous natural hazards in mountain areas are also directly related to the distribution of the snowpack and ice, and their evolution over time. This is the case for snow avalanches (Schweizer et al., 2008), and floods in mountain rivers and downstream areas (Gaál et al., 2015). To enable anticipation of the occurrence of snowrelated hazards and to reduce the threat to populations and infrastructure (Berghuijs et al., 2016; Tacnet et al., 2014); various models have been developed to reproduce and forecast the evolution of the snowpack on a daily or sub-daily basis.

Detailed snowpack models (Bartelt and Lehning, 2002; Vionnet et al., 2012) are increasingly coupled with hydrological models to forecast river discharges, and this depends on reliable simulation of snow and ice melting (Avanzi et al., 2016; Braun et al., 1994; Lehning et al., 2006). The more accurate the information on snowpack dynamics, the better will be the discharge forecasts based on hydrological models. However, the spatio-temporal distribution of the snowpack is highly variable in mountain areas (López-Moreno et al., 2011, 2013; Scipión et al., 2013; Seidel et al., 2016), and the runoff from mountain catchments depends on many interrelated processes that are highly variable in space and time, including infiltration, surface runoff, groundwater recharge, freezing of soil, and the snowpack distribution (Seyfried and Wilcox, 1995). For example, in areas where snow persists throughout the year the snowpack dynamics has a major impact on groundwater storage (Hood and Hayashi, 
The Cryosphere Discuss., https://doi.org/10.5194/tc-2017-184

Manuscript under review for journal The Cryosphere

Discussion started: 27 September 2017

(c) Author(s) 2017. CC BY 4.0 License.

2015). Finally, snowpack models are also combined with other models and techniques to forecast avalanche hazards (Bartelt and Lehning, 2002; Durand et al., 1999). Reproducing snowpack dynamics in heterogeneous mountain areas remains challenging. Some snowpack processes, including wind-induced redistribution and small scale topographic control on the snow distribution (Mott et al., 2010; Revuelto et al., 2016a; Schirmer et al., 2011; Trujillo et al., 2007; Vionnet et al., 2013) have not yet been fully integrated into numerical snowpack models which can be used operationally. Moreover, the additive nature of snowpack dynamics involves discrepancies between observed and simulated snowpacks, which can accumulate over the simulation period (e.g., Raleigh et al., 2015).

The various approaches available for running snowpack simulations range from punctual simulations (snowpack dynamics simulated for a particular location having specific characteristics) to semi-distributed and distributed approaches that simulate snow dynamics over broad areas.

The semi-distributed approach involves simulating the snowpack evolution over areas defined using discrete values for topographic variables including altitude, aspect, and slope (Fiddes and Gruber, 2012, 2014). The French numerical chain S2M (SAFRANSURFEX-MEPRA; Lafaysse et al., 2013), simulates the snowpack evolution using a semi-distributed approach. In this chain the SURFEX/ISBA-Crocus snowpack model (Vionnet et al., 2012; hereafter referred to as Crocus) is applied over a semi-distributed discretization of the French mountain ranges to diagnose the avalanche hazard for various topographic classes. Semi-distributed hydrological simulations are also widely used, which involves discretizing catchments into hydrologic response units (HRU), with the flow contribution from the HRUs being routed and compounded into an overall catchment discharge (Nester et al., 2012; Pomeroy et al., 2012). This simulation method is also applied to river discharge forecasting in mountain areas, with the output of semidistributed snowpack simulations used as inputs to the hydrological models (Braun et al., 1994).

The other modeling approach to simulating snowpack dynamics over extended areas is distributed simulations. This method involves simulation of the temporal evolution of environmental variables (e.g., snowpack or other hydrological variables) over a gridded representation of the terrain. In this approach the terrain is not discretized in classes; rather, it explicitly considers the characteristics (e.g. elevation, slope, aspect) for each 
The Cryosphere Discuss., https://doi.org/10.5194/tc-2017-184

Manuscript under review for journal The Cryosphere

Discussion started: 27 September 2017

(c) Author(s) 2017. CC BY 4.0 License.

pixel when simulating its snowpack evolution. Both approaches (distributed and semidistributed) have advantages and disadvantages, particularly the lower computing resource requirements of semi-distributed simulations, and the more accurate terrain representation of distributed simulations. Some snowpack processes cannot be reproduced using the semi-distributed approach, including wind-induced snow redistribution, small scale topographic control of precipitation, and terrain shadowing effects (Grünewald et al., 2010; Revuelto et al., 2014; Vionnet et al., 2014). However, evaluating the performance of these simulation approaches depends on the intended use of the simulations (Carpenter and Georgakakos, 2006; Orth et al., 2015). Similarly, the results obtained will depend on the spatial scale and the quality of the meteorological forcing model, and whether it is distributed or semi-distributed (Queno et al.; 2016; Vionnet et al., 2016). Many studies have compared the performance of hydrological models based on distributed and semi-distributed approaches in reproducing streamflow dynamics for alpine watersheds (Grusson et al., 2015; Kling and Nachtnebel, 2009; Li et al., 2015), but none have directly analyzed and compared representation of the spatiotemporal evolution of the snowpack using these simulation approaches. This is significant because direct implementation of the most promising advances in simulation requires the use of distributed simulations. This is the case for assimilation of satellite data (Charrois et al., 2016; Dumont et al., 2012a; Thirel et al., 2013); the inclusion of small scale processes in simulations, including snow redistribution by wind (Schirmer $e t$ al., 2011; Vionnet et al., 2014); and gravitational or topographic controls on snow movements (Bernhardt and Schulz, 2010; Christen et al., 2010; Revuelto et al., 2016a). Thus, comparison of distributed and semi-distributed simulations is needed to evaluate potential improvements, based on similar simulation setups (including the same study period and area, meteorological forcing, and simulation initialization). The newest meteorological models provide high spatial resolution information on the evolution of atmospheric variables (Seity et al., 2010); this is an improvement that distributed snowpack simulations can fully incorporate.

This study provided a comprehensive evaluation of semi-distributed and distributed snowpack simulations for a mountain catchment, using the Crocus snowpack model (Brun et al., 1992; Vionnet et al., 2012). We firstly assessed the ability of the model to simulate the snowpack evolution at a local scale for specific stations having continuous snow observation data. For these stations, the punctual simulations accounted for local 
The Cryosphere Discuss., https://doi.org/10.5194/tc-2017-184

Manuscript under review for journal The Cryosphere

Discussion started: 27 September 2017

(c) Author(s) 2017. CC BY 4.0 License.

132 topographic characteristics. These punctual simulations enabled initial analysis of the

133 capacity of the model to subsequently evaluate the distributed and semi-distributed

134 approaches to simulating the snowpack dynamics over a broader area, using the same

135 meteorological forcing. The simulation results obtained using the distributed and semi-

136 distributed approaches were compared with observations for the snow covered area

137 based on MODIS satellite sensors, the glacier surface mass balance (winter, summer,

138 and annual), and the glacier equilibrium-line altitude derived from satellite images

139 (Landsat, SPOT, and ASTER). This enabled assessment of the use of distributed

140 simulations for analysis of snow and ice dynamics. The simulations were based on data

141 for the upper Arve catchment (French Alps) for the 26 years from 1989 to 2015. 
The Cryosphere Discuss., https://doi.org/10.5194/tc-2017-184

Manuscript under review for journal The Cryosphere

Discussion started: 27 September 2017

(c) Author(s) 2017. CC BY 4.0 License.

\section{Study area}

143 The upper Arve catchment is located in the western Alps, France, between the northeast

144 slopes of the Mont Blanc massif and the southwest slopes of the Aiguilles Rouges massif. The catchment extends from the headwaters of the Arve River to the town of Chamonix (Fig. 1), and includes major tributaries carrying melt water from three glaciated areas (Arveyron de la Mer de Glace, Arveyron d'Argentière, and Bisme du Tour) to the main river. The upper Arve catchment covers $205 \mathrm{~km}^{2}$ and has a high degree of topographic heterogeneity, with steep slopes in some areas, and gentle slopes on large glaciated areas and at the lower elevation zones of the valley, which is a typical U-shaped glacial valley. Elevation ranges from 1020 to 4225 m.a.s.l., with $65 \%$ of the surface area above 2000 m.a.s.l. Glaciers cover 33\% of the area (Gardent et al., 2014), and $22 \%$ is covered by forests, mainly in the lower elevation areas. The water discharge regime is strongly dependent on the snow melt dynamics during spring and early summer, with the major contribution of melt water from glacierized areas occurring during late summer and autumn; this is termed a nivo-glacial regime of river discharge (Viani et al., submitted). The Mont Blanc and Aiguilles Rouges massifs are also highly spatially heterogeneous, having various slopes and aspects over a wide range of elevations in glaciated and non-glaciated areas; this affects the spatio-temporal evolution of snow and ice.

161 The area is one subject to severe flood hazards. This is a consequence of the steepness 162 of the terrain, which results in a rapid hydrological response to precipitation, the 163 typically rapid meteorological changes that occur in this mountain area (mainly 164 associated with convective episodes during spring and summer), and the high population densities and infrastructure in the bottom of the valley. 
The Cryosphere Discuss., https://doi.org/10.5194/tc-2017-184

Manuscript under review for journal The Cryosphere

Discussion started: 27 September 2017

(c) Author(s) 2017. CC BY 4.0 License.

\section{Methods}

\subsection{Simulation setup}

We used the Crocus snowpack model to simulate the temporal evolution of snow and ice in the upper Arve catchment. Crocus is a multilayer model that simulates snowpack evolution based on the energy and mass exchanges between the various snow layers within the snowpack, and between the snowpack and its interface with the atmosphere and the soil (i.e. the top and bottom of the snow column). The maximum number of layers in Crocus is set to 50. Crocus is implemented in the externalized surface model SURFEX (Vionnet et al., 2012). Within SURFEX (Masson et al., 2013), Crocus is coupled to the multilayer land surface model ISBA-DIF (Interaction between Soil, Biosphere and Atmosphere; diffusion version; Decharme et al., 2011).

The meteorological forcing required to drive the temporal evolution of the simulations was obtained from the SAFRAN meteorological analysis system (Durand et al., 1993). This provides the atmospheric variables needed to run ISBA-Crocus, including air temperature, specific humidity, long wave radiation, direct and diffuse short wave radiation, wind speed, and precipitation phase and rate. SAFRAN was specifically developed to provide meteorological forcing for mountain areas at a suitable elevational resolution. The SAFRAN analysis combines observational data obtained from automatic weather stations with manual observations with the guess from the global numerical weather prediction system ARPEGE (Courtier and Thépaut, 1994). We used SAFRAN re-analysis, which benefitted from meteorological observations not available in real time (Durand et al., 2009a, 2009b). This analysis system can provide outputs for punctual simulations, or semi-distributed outputs. In the first case the analysis is performed directly for the elevations of the stations involved, while in the second case the analysis is performed for 300-m elevation bands. In both cases the spatial extent of the analysis is approximately $1000 \mathrm{~km}^{2}$. These regions (known as "massifs") were defined by Durand et al. (1993) who took climatic homogeneity into account. In this study the SAFRAN analysis was only used for that part of the Mont Blanc "massif" which covers the entire study catchment. SAFRAN and SURFEX/ISBA-Crocus (hereafter SAFRAN-Crocus) are used in avalanche hazard forecasting in France, using the S2M chain (Lafaysse et al., 2013); this takes account of the altitude, aspect, and slope classes (semi-distributed simulation). 
The Cryosphere Discuss., https://doi.org/10.5194/tc-2017-184

Manuscript under review for journal The Cryosphere

Discussion started: 27 September 2017

(c) Author(s) 2017. CC BY 4.0 License.

\subsection{Punctual, semi-distributed, and distributed approaches}

The temporal evolution of snow and ice was simulated using punctual, semi-distributed, and distributed approaches, based on the same meteorological forcing.

\section{Punctual simulation}

Punctual snowpack simulations were performed for the five Météo-France stations within the study area, based on the elevation, slope, and aspect for each station. Punctual simulations included a topographic mask from a 50-m digital elevation model (DEM) to account for any terrain shadowing effect on simulation of the incoming shortwave radiation (provided by the SAFRAN meteorological model).

\section{$\underline{\text { Semi-distributed simulation }}$}

Snow and ice semi-distributed simulations were carried out based on the topographic classes of the SAFRAN model (300-m elevation bands from 900 m.a.s.l. to 4100 m.a.s.l) for eight aspect classes (north, northeast, east, southeast, south, southwest, west, and northwest) and two slope values $\left(20^{\circ}\right.$ and $\left.40^{\circ}\right)$. For each elevation band a simulation over flat terrain (no aspect classification) was also carried out. These topographic classes are the same as those used for avalanche forecasting (Lafaysse et al., 2013). To consider snow and ice evolution on glacierized and non-glacierized areas, two distinct simulations were run for all terrain classes, one involving a given thickness of ice to initialize the simulation, and another initialized using bare ground (see section $3.3)$.

In a final stage the snowpack semi-distributed simulations were assigned or re-projected onto the pixels of the study area DEM (the same DEM used for distributed simulations; 250x250 m grid size). The pixels were categorized according to the semi-distributed terrain classes: slopes from 0 to $10^{\circ}$ were considered flat, those from 11 to $30^{\circ}$ were assigned to the $20^{\circ}$ slope class, and those $>30.1^{\circ}$ were assigned to the $40^{\circ}$ class. From this categorization of the DEM the snowpack simulation outputs were assigned to each terrain class for all time steps. Thereby, for each time step a snow and ice distribution map was generated that spatially distributed the semi-distributed snowpack simulation obtained for the various terrain classes. This enabled comparison of the two approaches based on the same observation dataset.

\section{Distributed simulation}

The distributed snowpack simulations were performed in a DEM having a 250x250 m grid spacing and covering the $205 \mathrm{~km}^{2}$ of the study area. As SAFRAN reanalysis 
The Cryosphere Discuss., https://doi.org/10.5194/tc-2017-184

Manuscript under review for journal The Cryosphere

Discussion started: 27 September 2017

(c) Author(s) 2017. CC BY 4.0 License.

provides semi-distributed outputs, the meteorological forcing at hourly time steps was spatially distributed over the 250-m grid DEM using specific routines that accounted for the topographic characteristics of each grid cell, based on interpolated meteorological variables for the closest terrain classes (Vionnet et al., 2016). However, the meteorological model used was the same for all simulations, and only minor differences occurred because of the need to include the topographic characteristics of each pixel.

The distributed Crocus simulations included the elevation, aspect, slope, soil, and land cover characteristics for each pixel (the last two obtained from ECOCLIMAPII/Europe; Faroux et al., 2013) to simulate the evolution of the snowpack (snow and ice). A routine to account for the topographic shadowing effect of short wave radiation (Revuelto et al., 2016a) was included in the distributed simulations. The inclusion of particular pixel features and topographic shadowing is the main difference between the semi-distributed and distributed methods. Figure 2 shows a schematic representation of distributed and semi-distributed simulation approaches.

\subsection{Simulation initialization}

Snowpack simulations were run for the period 1989-2015. However, the ISBA ground state (including temperature and soil humidity) must be initialized to accurately reproduce the evolution of the snowpack. A spin-up simulation for the 1988-89 snow year (1 August 1988 to 31 July 1989) was repeated iteratively 10 times, to ensure a realistic ground state when launching simulations.

Similarly, to adequately replicate the snow and ice evolution over glacierized areas a glacier initialization was performed. Thus, for the simulations a sufficiently thick ice layer (several tens of meters) was incorporated beneath the snow layers to ensure glacier presence during each season in the glacierized areas. As Crocus is a multilayer snowpack model that simulates the energy and mass interchanges between the various snowpack layers, it also enables simulation of the glacier surface mass balance (Dumont et al., 2012a; Gerbaux et al., 2005; Lejeune et al., 2013). Glacierized areas were initialized at the beginning of each snow season (1 August) using a 40-m ice thickness (if the total ice thickness was less than this value), which ensured that it was present for the entire snow season (from 1 August of one year to 31 July of the next year). Thus, the six deepest Crocus layers were initialized with a density value of $917 \mathrm{~kg} / \mathrm{m}^{3}$ and a temperature of $273.16 \mathrm{~K}$ (the Crocus default density and temperature values for ice, and representative of temperate glaciers). The thickness of these layers progressively 
The Cryosphere Discuss., https://doi.org/10.5194/tc-2017-184

Manuscript under review for journal The Cryosphere

Discussion started: 27 September 2017

(c) Author(s) 2017. CC BY 4.0 License.

transitioned from a shallow thickness for the upper layer $(0.01 \mathrm{~m})$ to thicker layers in the deepest part of the ice (with a 5-fold difference factor between one layer and the one above); this resulted in a total ice thickness of $39.06 \mathrm{~m}$. The ice initialization was also performed during the spin-up of soil to reproduce the ground state over glaciarized areas. The extent of glacierized areas was based on the most recent data on their surface area, inventoried in 2012 (Rabatel et al., 2013). Although other historic surface inventories of glacierized areas within the upper Arve catchment were available (1986 and 2003; Gardent et al., 2014), the most recent inventory was used for simplicity because the change in the glacierized surface area between the inventoried dates represents less than a $1 \%$ of the total study surface area.

\subsection{Evaluation strategy}

The availability of direct snow and ice observations for mountain areas is limited. Broadly, when the time between observations is short, the spatial extent is limited and oppositely, when large areas are observed, the temporal frequency is low. Consequently, evaluation of the performance of a model in reproducing the snowpack evolution is difficult because of a lack of information. Although we did not evaluate a hydrological model in this study, the "observation scale" defined by Blöschl and Sivapalan (1995) aided assessment of the representativeness of the available observations. The observation scale is defined by: i) the spatial/temporal extent (coverage) of a dataset; ii) the spacing (space and time resolution) between samples; and iii) the integration volume (time) of a sample (also known as support). These three criteria can rarely be optimized simultaneously. Hanzer et al. (2016) introduced a representation to depict the suitability of an observation dataset to evaluate model performance. To evaluate the simulations in this study we used four datasets based on: in situ snow depth from Météo-France stations; the snow covered area (SCA) from MODIS images; the punctual glacier surface mass balance (SMB); and the glacier equilibrium-line altitude (ELA) from Landsat/SPOT/ASTER. Based on the radar charts presented by Hanzer et al. (2016), shown in their Figure 5, it was possible to fully evaluate the simulations using the four observation datasets available for this study. The analyses presented below enabled us to draw conclusions about the impact of the methods used on the various spatiotemporal scales considered, also enabling an overall evaluation of the simulation platform. 
The Cryosphere Discuss., https://doi.org/10.5194/tc-2017-184

Manuscript under review for journal The Cryosphere

Discussion started: 27 September 2017

(c) Author(s) 2017. CC BY 4.0 License.

297 The four datasets used in evaluation of the simulations are described below. Not all

298 simulations (punctual, semi-distributed, and distributed) were evaluated using all four

299 observation datasets. The punctual snow depth simulations only provided a preliminary

300 evaluation of the simulation setup in terms of reproducing the temporal snowpack

301 evolution, so only punctual snow depth observations were used in the evaluation of this

302 simulation approach. The three other datasets (SCA, and glacier SMB and ELA) were

303 used in evaluating the semi-distributed and distributed simulations, as these datasets had

304 the appropriate spatial and temporal extents needed to assess the performance of these

305 two approaches.

\section{$306 \quad$ Punctual snow depth observations}

307 The Météo-France observation network has 5 stations in the study area (Fig. 1), located

308 at different elevations. Some of these stations acquired data during all snow seasons

309 throughout the entire study period, including at Nivose Aiguilles Rouges (2365 m.a.s.1.),

310 Chamonix (1025 m.a.s.l.), and Le Tour (1470 m.a.s.l.). Other stations were installed

311 later, and provided observational data since the 1994-95 snow season (Lognan station;

3121970 m.a.s.l) and since the 2003-04 snow season (La Flegere station; 1850 m.a.s.1.). At

313 these stations the temporal evolution of the snow depth was observed at daily or sub-

314 daily time intervals, and these data were used to evaluate SAFRAN-Crocus in non-

315 glacierized areas during winter and spring (periods with snow presence).

316 Snow cover area based on the MODIS sensor

317 i) Evolution of the snow covered area

318 Many studies have demonstrated the usefulness of MODIS images for snow cover 319 mapping in mountain areas (Gascoin et al., 2015; Klein and Barnett, 2003; Parajka and 320 Blöschl, 2008). The MODIS mission database provides long temporal coverage (the 321 mission was launched in 2000, and obtains daily images), so enabled a comparison 322 between the simulated and observed snow cover evolution for 14 snow seasons (out of 323 the 26) simulated on an almost daily basis (comparisons were limited by cloud cover in the study area). Sub-pixel snow monitoring of the snow cover at 250-m spatial resolution was performed using MODImLab software (Dumont et al., 2012b; Sirguey et al., 2009). Multispectral fusion between MOD02HKM (500 m; bands 3-7) and MOD02QKM (bands 1 and 2) (Sirguey et al., 2008), enabled this software to generate images at $250 \times 250 \mathrm{~m}$ spatial resolution to derive various snow-ice products. We used 
The Cryosphere Discuss., https://doi.org/10.5194/tc-2017-184

Manuscript under review for journal The Cryosphere

Discussion started: 27 September 2017

(c) Author(s) 2017. CC BY 4.0 License.

snow-ice products for assessing evolution of the SCA (Charrois et al., 2013). We also considered the cloudiness product in MODImLab to determine the proportion of the catchment affected by cloud cover. Generation of the UWS and cloudiness products in MODImLab software was based on the same DEM used for the snowpack simulations. This ensured a direct match between of observation and simulation pixels. To avoid errors related to cloud presence in the study area, only days having cloud cover representing $<20 \%$ of the total surface area were considered in the analysis.

The UWS threshold for considering a pixel to be snow covered was set to 0.35 (i.e., fractional snow cover > 35\%; Charrois et al., 2013; Dedieu et al., 2016). Three snow depth threshold values (0.10, 0.15, and $0.20 \mathrm{~m}$ (Gascoin et al., 2015; Quéno et al., 2016) were examined to consider a pixel as snow covered in the simulations.

The temporal evolution of the snow covered area (SCA) within the study area predicted by each simulation approach (semi-distributed and distributed) was analyzed in terms of the root mean squared error (RMSE), the mean absolute error (MAE), and $R^{2}$ for comparisons between simulations and observations. The temporal evolution of the SCA for specific snow seasons was also analyzed to assess the difference between observations and simulations in different time periods. The SCA evolution in forested areas was not evaluated, and these areas were masked in the analysis.

ii) Evaluation of spatial similarity

The spatial similarity between the observed and simulated SCA was evaluated for each simulation approach based on two similarity metrics: the Jaccard index (J), and the average symmetric surface distance (ASSD). As the grid cells coincided because the simulations and observations were based on the same DEM, we were able to obtain binary maps of snow presence from the simulated and observed maps, using the thresholds established.

The Jaccard index is the ratio of the intersection between the observed $(\mathrm{O})$ and the simulated (S) SCA and the union of $\mathrm{O}$ and $\mathrm{S}$ (Equation 1). The index values range from 0 to 1 , with a value of 1 representing a perfect match between the observed and simulated SCA.

$$
J=\frac{|O \cap S|}{|O \cup S|}
$$

The ASSD is complementary to J, as it evaluates the distance between the boundaries of the observed and simulated SCA. ASSD is based in the modified directed Hausdroff distance between boundaries (Dubuisson and Jain, 1994; see Quéno et al., 2016 and 
The Cryosphere Discuss., https://doi.org/10.5194/tc-2017-184

Manuscript under review for journal The Cryosphere

Discussion started: 27 September 2017

(c) Author(s) 2017. CC BY 4.0 License.

Sirguey et al., 2009 for more details). The ASSD unit is meters, and the smaller the distance the better the match between surface boundaries. The Jaccard index and ASSD were calculated for the 2001-02 to the 2014-15 snow seasons. To assess the performance of the two SCA simulation approaches for specific periods, the 2006-07 and 2007-08 snow seasons (both of which were characterized by low average levels of snow accumulation) and the 2011-12 and 2012-13 snow seasons (characterized by high levels of snow accumulation) were analyzed for both the accumulation period (January, February, and March; JFM) and the melt period (May, June, and July; MJJ).

\section{Glacier surface mass balance}

Glaciers located in the Mer de Glace and Argentière sub-catchments have been monitored, in a sufficient number of measurement locations for our analysis, since 1995 by the French Service National d'Observation GLACIOCLIM. During this period field data were obtained twice per year, during the maximum (end April-May) and minimum (around October) snow accumulation periods. These data enabled calculation of the SMB for summer (SSMB; annual difference between the maximum and minimum acquisitions), winter (WSMB; annual difference between the minimum of the previous year and the maximum acquisitions), and annually (ASMB; year to year differences in the minimum acquisitions) at each individual point of the network (Fig. 3). The observation procedure involved use of glaciological methods (Cuffey and Paterson, 2010) to retrieve the surface mass balance for the various time periods (SSMB, WSMB, and ASMB). Stakes (markers over the glaciers) are set up in both accumulation and ablation areas throughout the glaciers, and so reflect the evolution of the various zones of the glaciers. The spatial distribution of the stakes is shown in Figure 3. For further information on the methods for SMB data collection, see Réveillet et al. (2017).

The observations of SMB for the various time periods at more than 65 locations encompassing different glaciers enabled assessment of the snow and ice evolution over glacierized areas, as these measurements included snow and ice ablation (SSMB) and snow accumulation (WSMB) periods. Thus, the simulated SMB for the same observation periods and locations were computed based on Crocus results. With this information, a linear regression and $\mathrm{R}^{2}$ coefficient were computed for each sub-basin for the three periods, and these were used to measure the performance of the modeling approaches. The simulated (distributed and semi-distributed) and observed temporal evolutions of the SMBs were compared based on the SAFRAN elevation bands (the 
The Cryosphere Discuss., https://doi.org/10.5194/tc-2017-184

Manuscript under review for journal The Cryosphere

Discussion started: 27 September 2017

(c) Author(s) 2017. CC BY 4.0 License.

396 average and standard deviation for all points within each band were calculated). To

397 assess any elevational dependence of the SMB, the seasonal evolution of the observed

398 and simulated SSMB, WSMB, and ASMB were compared for two snow seasons having

399 opposite characteristics (high and low levels of snow accumulation) for the Mer de

400 Glace glacier, which had a large gradient for assessing elevational dependence.

401 Glacier equilibrium-line altitude

402 The glacier equilibrium-line altitude (ELA) is the annual maximum elevation of the

403 snow-ice transition over glacierized areas. Since 1984 the temporal evolution of the

404 ELA for the five largest glaciers in the study area has been monitored using various

405 satellite sensors (Rabatel et al., 2013, 2016). Data on the inter-annual evolution of the

406 ELA for the Tour, Argentière, and Mer de Glace glaciers (and its main tributaries, the

407 Leschaux and Talèfre glaciers) was available for the entire study period

408 Images from Landsat 4TM, 5TM, 7 ETM+, SPOT 1-5, and ASTER were used to obtain

409 the ELA for the study period. The spatial resolution of these images ranges from 2.5 to

$41030 \mathrm{~m}$. The method of snow line delineation using multispectral images combining

411 green, near-infrared, and short-wave infrared bands has been fully described by Rabatel

412 et al. (2012). The satellite acquisition date depends on various factors including the

413 availability of satellite images for the study area and cloud presence, but images

414 obtained during the period of minimum snow accumulation (late August to early

415 October) were used to obtain the ELA. Thus, the simulated ELA was obtained for the

416 same dates as the satellite acquisitions. Because of the difference in the spatial

417 resolution of the simulation $(250 \mathrm{~m})$ and satellite observations $(\leq 30 \mathrm{~m})$, the average and

418 standard deviations of the ELA were compared. 
The Cryosphere Discuss., https://doi.org/10.5194/tc-2017-184

Manuscript under review for journal The Cryosphere

Discussion started: 27 September 2017

(c) Author(s) 2017. CC BY 4.0 License.

\section{Results}

\subsection{Punctual snow depth}

The observed and simulated snow depth evolution for the 2007-08 and 2012-13 snow seasons (low and high average snow accumulation years, respectively) for the five stations are shown in Figure 4. The snow depth evolution shows the capacity of the SAFRAN-Crocus model chain to reproduce the temporal evolution at locations having differing topographic characteristics.

It is important to note that the results shown in Figure 4 indicate the capacity of the simulations to reproduce snow depth dynamics at specific points having well known topographic characteristics. Punctual simulations include the impact of surrounding topography on incident solar radiation (terrain shadowing masks). Additionally, the meteorological forcing was taken at the station elevation (SAFRAN forcing not yet discretized on elevation bands). Nevertheless, the spatial scale of the meteorological forcing was that of the Mont Blanc SAFRAN massif. Therefore the spatial variability of solid/liquid precipitation within the massif is not taken into account.

Some snow accumulation events were underestimated or overestimated in the SAFRAN-Crocus simulation, evident in discrepancies between the simulated and observed snow depths, including for the Le Tour (overestimation) and La Flégère (underestimation) stations for the 2007-08 snow season. Despite these discrepancies resulting from meteorological forcing, the simulated evolution of the snow depth appeared reliable, in particular during melt periods.

Table 1 shows the RMSE and bias errors between observations and simulations at the five stations. There was a high level of variability between the errors for the various stations, mainly because all local effects were not included in the simulations. It is noteworthy that the number of observations available and the time periods (which could have marked differences on total seasonal snow accumulation) affected the significance of the RMSE and bias for the various stations (Table 1). The RMSE values ranged from 20.8 to $66.6 \mathrm{~cm}$ and the bias ranged from -19.1 to $49.4 \mathrm{~cm}$. These values are small relative to the total snowpack thickness (snow depth observations were commonly > $200 \mathrm{~cm}$, and in some cases exceeded $300 \mathrm{~cm}$ ). However, for the Aiguilles Rouges station the RMSE and bias estimates were higher than for the other stations. This may be because this station is exposed to major wind-induced snow transport episodes that were not accounted for in the simulation. In addition to these events, this station is also 
The Cryosphere Discuss., https://doi.org/10.5194/tc-2017-184

Manuscript under review for journal The Cryosphere

Discussion started: 27 September 2017

(c) Author(s) 2017. CC BY 4.0 License.

452

453

454

455

456

457

458

459

460

461

462

463

464

affected by forecasting errors related to the meteorological forcing, such as the large underestimation for the first snowfall in 2007-08.

\subsection{Snow Cover Area evaluation}

Figure 5 shows an example of the SCA obtained using the UWS product for 24 July 2008, and the corresponding simulated snow depth determined using the distributed approach. This date was selected because it was a cloud-free day with high elevation areas covered by snow.

Table 2 shows the SCA simulation results estimated based on $0.1,0.15$ and $0.2 \mathrm{~m}$ snow depth thresholds compared with the observed UWS (0.35 threshold), for the 2008-09 and 2009-10 snow seasons (average snow accumulations). In light of these results we selected a $0.15 \mathrm{~m}$ snow depth simulation threshold for deciding whether a pixel was snow covered.

\section{i) Evolution of the snow covered area}

The results of simulation of the SCA in the study area for 10 of the 14 snow seasons (for ease of visualization) based on MODIS data are shown in Figure 6. This figure shows that both approaches were able to reproduce the SCA evolution based on MODIS images. During winter and early spring, when large areas of the catchment are covered with snow, there was a high degree of consistency between the observations, and simulations based on each approach. In contrast, during summer and early autumn, when snow is only present at high elevations and on preferential accumulation areas, there was less consistency between observations and simulations, particularly for the semi-distributed simulations.

Figure 7 shows the SCA evolution for four non-consecutive snow seasons, two having low levels of snow accumulation (2006-07 and 2007-08 seasons) and two having high levels of snow accumulation (2011-12 and 2012-13 seasons). In winter the simulation slightly overestimated the SCA compared with observations, but during summer and autumn the simulations underestimated the SCA. However, the distributed simulations most closely reproduced the observed SCA (Table 3). In all four seasons the semidistributed simulations generated larger underestimates of the SCA during summer and early autumn.

Using the terrain aspect classification for semi-distributed simulations it is possible to evaluate the impact of terrain shadowing effects. From the eight orientation classes we identified two main groups: those having a northern aspect (N, NW, NE) and those 
The Cryosphere Discuss., https://doi.org/10.5194/tc-2017-184

Manuscript under review for journal The Cryosphere

Discussion started: 27 September 2017

(c) Author(s) 2017. CC BY 4.0 License.

having a southern aspect (S, SE, SW). Figure 8 shows the observed and simulated SCA evolution for high and low snow accumulation seasons in relation to these two terrain classes. The variability in the SCA was well captured for both aspects by both the semidistributed and distributed simulations. Error estimates for the SCA simulated in relation to the north and south aspects (Tables 4 and 5) were lower for the distributed simulations compared with the satellite observations. Moreover, the SCA temporal evolution shown in Figure 8 shows that overall the simulation underestimated the SCA, during late spring and summer in northern aspects. For southern aspects, simulation of the SCA evolution was poorer during winter.

ii) Evaluation of the spatial similarity

The spatial similarity between the observed and simulated SCA is exemplified in the temporal evolution of the Jaccard index and ASSD. Table 6 shows the average values for J and ASSD for the entire study period and for the 2006-07 and 2007-08 snow seasons (low levels of snow accumulation) and the 2011-12 and 2012-13 snow seasons (high levels of snow accumulation).

The higher scores found during seasons having high levels of snow accumulation were expected because of the larger areas covered by snow. Figure 9 shows the temporal evolution of the Jaccard index and ASSD for high and low level snow accumulation seasons. Although the difference between the distributed and semi-distributed simulations was low for most dates, the Jaccard index values for the distributed simulations were higher, showing a greater capacity for simulating the SCA (Table 6). Similarly, ASSD values were lower for distributed simulations, which showed reduced distances between the limits of snow free and snow covered areas. The differences between the two approaches are also evident in the average values shown in Table 6 .

The performance of the simulations appeared to differ between periods of maximum and minimum snow accumulation (Fig. 9). Table 7 shows the average Jaccard and ASSD index values obtained for the JFM and MJJ periods for the four snow seasons analyzed in detail (high and low level snow accumulation seasons). The better performance of distributed simulations was a result of better reproduction of the SCA evolution, and their ability to capture better spatial patterns in heterogeneous mountain terrain. Not surprisingly, the values in Table 7 also show higher scores for both simulations during winter and early spring, when the SCA was high. 
The Cryosphere Discuss., https://doi.org/10.5194/tc-2017-184

Manuscript under review for journal The Cryosphere

Discussion started: 27 September 2017

(c) Author(s) 2017. CC BY 4.0 License.

518

519

520

521

522

523

524

525

526

527

528

529

530

531

532

533

534

535

536

537

538

539

540

541

542

543

544

545

546

547

548

549

550

\subsection{Glacier surface mass balance}

Analysis of the glacier surface mass balance enabled assessment of the effectiveness of simulations of the seasonal and annual evolution of snow and ice on glacier surfaces. Figures 10 and 11 show the simulated and observed temporal evolution of the surface mass balance for the 300-m elevation bands. These show good agreement between observations and simulations with respect to year-to-year SMB variability. During winter the snow accumulation at high elevations was underestimated. For elevations above 2700 m.a.s.l. a higher positive glacier SMB was observed, and the difference between the observed and simulated SMB increased at higher elevations. During summer, when solid precipitation has no or marginal influence in low elevation areas and little influence at higher elevations, the observed and simulated SMB values were similar for elevations above 2100 m.a.s.l. for the Mer de Glace glacier, and above 2400 m.a.s.l. for the Argentière glacier. Nevertheless, in high elevation areas the SSMB deviation was also underestimated on the simulations. This was probably because of the lower level of snow accumulation simulated during winter (using SAFRAN model) which induces an earlier complete melting of snow in the simulation in low elevations. This is presumably because of more rapid melting of ice insulated from solar radiation by the snow layers above, and because of the impact of variations in wind speed or long wave radiation on the simulation.

Combination of the simulated WSMB and SSMB produced an ASMB that underestimated snow accumulation at high elevations (> 3000 m.a.s.l.) and melting at low elevations (2400 m.a.s.l. for the Argentière glacier, and < 2400 m.a.s.l. for the Mer de Glace glacier). Thus, the glacier ASMB included summer and winter variations, which in some cases negated each other. The contrasting performance of the simulations in reproducing the SMB between high and low elevations is clearly illustrated in Figure 12. This shows the altitudinal dependence of the SMB for two snow seasons, one having a low level of snow accumulation and the other a high level. The simulated SSMB, WSMB, and ASMB values for both approaches underestimated the observed values at both low (higher negative loss of water equivalents observed) and high (lower positive loss of water equivalents observed) elevation areas. Nevertheless, the SMB simulations at intermediate elevations correctly reproduce the observed values, and the temporal evolution of the SMB for the 20 years (Figs 10 and 11) was well reproduced by the simulations. 
The Cryosphere Discuss., https://doi.org/10.5194/tc-2017-184

Manuscript under review for journal The Cryosphere

Discussion started: 27 September 2017

(c) Author(s) 2017. CC BY 4.0 License.

551 The performance of simulations in reproducing glacier SMB must take account of the

552

553

554

555

556

557

558

559

560

561

562

563

564

565

566

567

\begin{abstract}
areal extent at differing elevations. Elevations > 3000 m.a.s.l. represent 37\% and 52\%
\end{abstract}
of the surface areas of the Argentière and Mer de Glace glaciers, respectively. The

Argentière glacier has $<10 \%$ of its surface area below 2400 m.a.s.l., and the Mer de Glace glacier has $<7 \%$ below 2100 m.a.s.l. These relative extents of glacierized surface area show that for large areas of the glaciers the SMB was accurately reproduced by the simulations. However, for large glacierized areas there were marked differences between the observations and simulations; although the year-to-year evolution was accurately reproduced, this demonstrates the need to improve simulation methods.

In general, the distributed simulation values for the SMB were slightly closer to the observed SMB values than were those from the semi-distributed simulations. Table 8 shows that the RMSE values were lower for the distributed simulations and the $\mathrm{R}^{2}$ values were higher for most periods in both glacierized areas. However, the WSMB simulations obtained using the semi-distributed approach were slightly better at reproducing the SMB.

\title{
4.4. Glacier Equilibrium Line Altitude
}

The temporal evolution of the ELA for the five largest glaciers in the study area is shown in Figure 13. Overall, and despite differences in the spatial resolutions of simulations and observations of ELA, the ability of the simulations to capture the temporal evolution of the ELA during the 26 years of the study was satisfactory, with lower variations found for distributed simulations for most seasons.

Table 9 shows the average absolute differences between observations and simulations and the linear adjustments for the five glaciers. These results show a systematic positive bias on the simulated ELA which is consistent with the summer underestimation revealed by the previous tests. 
The Cryosphere Discuss., https://doi.org/10.5194/tc-2017-184

Manuscript under review for journal The Cryosphere

Discussion started: 27 September 2017

(c) Author(s) 2017. CC BY 4.0 License.

576

577

578

579

580

581

582

583

584

585

586

587

588

589

590

591

592

\section{Discussion}

\subsection{Overview of SAFRAN-Crocus performance}

The observation dataset used in this study enabled multilevel spatio-temporal validation of the performance of snowpack simulations at the scale of a large alpine catchment. The analysis of the results of semi-distributed and distributed simulations provided a holistic evaluation of the snow and ice dynamics in the study area. Overall, the SAFRAN-Crocus simulations have shown a good capability on reproducing the temporal evolution and spatial variability of snow and ice during the study period.

The simulations were evaluated using snow depth data from five Météo-France stations. Their ability to reproduce a bulk variable such as snow depth suggests that the main simulation processes were satisfactory, especially those related to the various components of the energy and mass balance. These findings are consistent with previous evaluations of the SAFRAN-Crocus system (Durand et al., 2009a; Lafaysse et al., 2013).

Distributed information on the snowpack evolution from the MODIS sensor enabled evaluation of the simulation results on a suitable temporal scale. Although many MODIS images were discarded because of cloud cover, they demonstrated the capacity of SAFRAN-Crocus to simulate the spatial distribution of the SCA over time for large areas having high spatial heterogeneity. The 14-year time period spanned is longer than in all previous similar evaluations, and at a higher spatial resolution (Quéno et al., 2016). Evaluation of the spatial similarity between simulations and observations (Jaccard index and ASSD) showed that the SCA spatial pattern was well reproduced. The simulated SCA for winter was in close agreement with observations, as most of the study area was covered by snow. In contrast, during summer the performance of simulations declined, as evidenced by the increase in ASSD and the decrease in the Jaccard index. As small scale topographic effects that control snow accumulation on preferential accumulation areas were not included in the simulations, deviations from observations would have increased for certain periods, particularly the late melt period. These processes, which are mainly driven by small topographic features, can be longlasting during the late melt period (Revuelto et al., 2016b; Sturm and Wagner, 2010). This was particularity evident in comparisons of the scores for the 2006-07 and 200708 periods with those for the 2011-12 and 2012-13 periods (Table 3). The differences in response may have originated from the higher weight of glacier melt processes in 
The Cryosphere Discuss., https://doi.org/10.5194/tc-2017-184

Manuscript under review for journal The Cryosphere

Discussion started: 27 September 2017

(c) Author(s) 2017. CC BY 4.0 License.

609

610

611

612

613

614

years with shallow snow depth. For these years, the good capability of the model on reproducing snow melting is lumped because the snow distribution is not appropriately simulated.

The availability of observations of the glacier SMB over a long time period provided an opportunity to evaluate the performance of the simulations in capturing the snow and ice temporal evolution over a wide range of elevations over glacierized areas. Contrasting simulation performances were found in the various elevation bands, and changed with the time period involved (summer, winter, or annual scales). The performances in simulating the SMB for the Argentière and Mer de Glace glaciers differed at high and low elevations. Although the observed SMB was always higher than the simulated one for elevations exceeding $2700 \mathrm{~m}$, the opposite was observed for areas having elevations below $2100-2400 \mathrm{~m}$. As the temporal variability of solid precipitation generally explains the temporal variability of the WSMB (Réveillet $e t$ al., 2017), it is important to consider differences between simulated and observed solid precipitation, and how these could affect underestimation of the SMB in simulations. Studies in the same study area and nearby glaciers suggest that at high elevations the SAFRAN reanalysis may underestimate solid precipitation at ratios ranging from 1:1.2 at 2000 m.a.s.l. and 1:2.0 at 3200 m.a.s.l., with an average of 1:1.5 at the glacier scale ( Gerbaux et al., 2005; Réveillet et al., 2017; Viani et al., submitted). This mainly results from the lack of precipitation observations at high elevations available for assimilation into the SAFRAN reanalysis; consequently divergences increase with elevation. Despite this shortcoming, the simulations captured the inter-annual fluctuation of the WSMB for all elevation bands. During summer the SMB could be explained by temperature variability in the two glaciers (Réveillet et al., 2017), thus simulations results are closer to observations, particularly at higher elevations. In summer, most precipitation is liquid, and so has little impact on the energy balance of the glaciers (Hock, 2005); this may explain the improvement in summer simulations for most elevations.

It has recently been shown that Crocus is able to accurately simulate snow albedo (Réveillet et al., in prep), which is important because of its influence on the surface mass balance (Essery and Etchevers, 2004; Essery et al., 1999). However, it has been demonstrated that Crocus results are directly affected by uncertainties in the estimation of long wave radiation and wind (Réveillet et al., in prep). Such effects may be significant for elevations where the snow completely melts during summer and do not 
The Cryosphere Discuss., https://doi.org/10.5194/tc-2017-184

Manuscript under review for journal The Cryosphere

Discussion started: 27 September 2017

(c) Author(s) 2017. CC BY 4.0 License.

642 insulate ice from the atmosphere during late melt season; this includes the low elevation

643 areas of glaciers, where high SSMB errors were found. At the annual time scale, glacier

644 differences between the observed and simulated SMB at high elevations during winter

645 and at low elevations during summer were reduced because the SMB underestimates for

646 winter (note these were negative/positive at high/low elevations) were compensated for

647 by more accurate simulations during summer, and vice versa. Regardless of these errors,

648 SAFRAN-Crocus was able to replicate the interannual evolution of the SMB.

649 Additionally, there was a good match between observations and simulations for the

650 2100-2400 to 3000 m.a.s.l. elevation bands for the Mer de Glace and Argentière

651 glaciers, respectively; these elevation bands encompassed large proportions of the

652 glaciers (approximately 40 and 53\%, respectively).

653 For the entire study period the SAFRAN-Crocus simulations effectively reproduced the 654 observed inter-annual evolution of the study area glacier ELA. However, some 655 differences were evident, particularly on steeper glaciers, because the high spatial 656 heterogeneity was not well captured by the simulations. For mid-latitude mountain 657 glaciers, the annual evolution of the ELA can be considered to be a good proxy for the 658 glacier surface mass balance (Braithwaite, 1984; Rabatel et al., 2005). Thus, 659 observations of the glacier SMB, together with the ELA, provide for a complete 660 evaluation of glacier temporal evolution.

661 5.2. Limitations of the evaluations performed

662 Although the observation dataset enabled comprehensive evaluation of the simulations, 663 it had limitations. First, the discrepancy in spatial scale between the SAFRAN 664 meteorological analysis and the snow depth observations, and the low number of 665 stations, limited the interpretation of results in terms of the simulated snow depth. 666 Differences in the temporal evolution of snow depth between observation and 667 simulations were in part associated with the unresolved sub-massif spatial variability in 668 the level of precipitation, as previously described (Durand et al., 2009a; Lafaysse et al., 669 2013; Vionnet et al., 2016). In situ observations are also subject to local effects 670 associated with the topographic control at each site, including exposure to dominant 671 winds, which markedly affects the snow depth dynamics. Such effects remain difficult 672 to capture in snowpack modeling (Dadic et al., 2010a; Liston et al., 2007; Revuelto et 673 al., 2016a; Schirmer et al., 2011; Vionnet et al., 2014), and were not included in the 674 modeling involved in our study. Discrepancies originating from the snow-rain limit can 
The Cryosphere Discuss., https://doi.org/10.5194/tc-2017-184

Manuscript under review for journal The Cryosphere

Discussion started: 27 September 2017

(c) Author(s) 2017. CC BY 4.0 License.

675

676

677

678

679

680

681

682

683

684

685

686

687

688

689

690

691

692

693

694

695

696

697

698

699

700

701

702

703

704

705

706

707

also influence the snow depth. Stations at high elevation (Aiguilles Rouges: 2365 m.a.s.l.) are typically not affected by this phenomenon during winter, as the $0^{\circ} \mathrm{C}$ isotherm is located at lower elevations. In contrast, low elevation stations (Le Tour: 1470 m.a.s.l.; Chamonix: 1025 m.a.s.l.) are potentially affected by differences between the simulated and observed snow-rain limit, even during winter. In mid-latitude regions including the Alps, elevational shifts in the $0^{\circ} \mathrm{C}$ isotherm cover a significant variation throughout the year, including the elevations where each of the stations in this study is located.

Data on the spatial extent of SCA derived from MODIS images enabled distributed evaluation of the simulations. However, its usefulness in analysis of the performance of spatial simulations is limited, as it does not provide information on other snowpack variables, and imposes restrictions on the spatial resolution. Satellite observations also involve uncertainty, depending on the routines applied for generating the final product and the thresholds used to decide whether a pixel area as covered by snow. We adopted a 0.35 UWS threshold for considering a pixelas snow covered in satellite imagery (Charrois et al., 2013; Dedieu et al., 2016). We also performed an analysis to select the simulated snow depth threshold for considering a pixel to be snow covered. The $0.15 \mathrm{~m}$ threshold selected is consistent with values reported in previous studies (Gascoin et al., 2015; Quéno et al., 2016). In addition to the above issues, satellite products can have errors for specific dates. For a small number of days during the study period the SCA obtained from MODIS images did not describe the real extent of snow cover. For these days the SCA did not match the temporal SCA evolution observed on previous and later dates. Furthermore, days having the maximum cloud cover allowed in our analysis could have $\pm 20 \%$ SCA variability. This induces uncertainty in the observation for certain dates which can be greater than this of the pixel classification as snow covered in the simulations (note the $\pm 0.05 \mathrm{~m}$ snow depths threshold tested). In addition, pixels classified as snow covered in which bare soil may have a non-negligible extension (pixels close to the 0.35 UWS threshold) could introduce discrepancies between observations and simulations, mainly during summer.

Glacier surface mass balance observations also involve limitations. For instance, infrequent glacier SMB observations for certain temporal windows limited evaluation of the simulated SMB. The spatial sampling involved in the glaciological method can also be a significant source of uncertainty, especially for elevation bands for which there are 
The Cryosphere Discuss., https://doi.org/10.5194/tc-2017-184

Manuscript under review for journal The Cryosphere

Discussion started: 27 September 2017

(c) Author(s) 2017. CC BY 4.0 License.

708 a limited number of observations. Additionally, the average SMB obtained for the elevation bands can lump the high SMB spatial variability that occurs within a specific band. For most years and all the elevation bands the uncertainty associated with the average SMB measurements ( $\pm 0.2 \mathrm{~m}$ water equivalent; Réveillet et al., 2017) was exceeded by the uncertainty associated with the observations for each band. This could have affected the results presented here, indicating that the standard deviations for the observed SMB values should be retained when analyzing the results of the simulations. The simulations underestimated the observed SMB for the lowest elevations having SMB observations, despite the temporal variability being replicated. This may have been related to errors in precipitation and phase, and in this regard differences in the snow-rain limit could be important. Additionally, the impact of local effects is more important at low elevations, as glaciers are more confined in valleys that have very steep slopes and adjacent high mountains. In low elevation areas, where ice is exposed to the atmosphere for longer periods during the year (snow does not insulate ice from the atmosphere since it has disappeared), differences in meteorological forcing variables including wind and temperature can have a marked influence on simulation results (Réveillet et al., submitted). Similarly, at low elevations the glaciers are usually covered by debris, as is the case for the Mer de Glace glacier. This was not considered in our simulations, but differences in the behavior of the snow-ice interface in debris-covered areas could be expected to affect the simulation results (Lejeune et al., 2013). Some issues were also evident in evaluation of the ELA. For the smallest glaciers, a reduced number of pixels having the $250-\mathrm{m}$ pixel resolution were considered. As the ELA observations were based on Landsat, SPOT and ASTER satellite images (2.5-30 $\mathrm{m}$ resolution) the spatial variability of the simulation made it difficult to identify the glacier margins. The combination of problems in delimitating glaciated areas over smaller ice bodies, and the smooth topography characterizing the simulations compared with real terrain, could cause simulation errors for smaller glaciers. 5.3. Distributed vs. semi-distributed approaches

736 In this study we performed distributed and semi-distributed snowpack simulations using 737 the same model and evaluation setup (including ice initialization, meteorological 738 forcing, projection on the same grid, observation databases). Thus, both approaches were affected by the same methodological limitations. The simulation results were consistent with the observed SCA evolution using both approaches. However, better 
The Cryosphere Discuss., https://doi.org/10.5194/tc-2017-184

Manuscript under review for journal The Cryosphere

Discussion started: 27 September 2017

(c) Author(s) 2017. CC BY 4.0 License.

741 results were obtained from the distributed simulations, especially during late summer.

742 The energy balance was more accurately simulated in the distributed approach, as it 743 accounted for terrain shadowing effects on incoming solar radiation. The distributed

744 simulations also accounted for the specific characteristics of each pixel rather than 745 categorization based on topographic classes. The distributed approach also produced 746 more accurate simulations of the SCA for the various time periods, particularly during 747 the late melt period. Similarly, spatial similarity evaluation (Jaccard index and ASSD)

748 also showed that the distributed approach was slightly superior at reproducing the SCA 749 distribution. The semi-distributed approach better simulated the temporal evolution of 750 the SCA for areas having a southern aspect, because of terrain shadowing effects in 751 areas having a northern aspect are not appropriately considered. Oppositely, the 752 simulation in northern aspects obtained with the distributed approach is superior 753 because these are able to include terrain shadowing on the simulations.

754 Based on the glacier SMB scores and their temporal evolution, we concluded that the 755 best simulation approach depends on the season involved. Thus, the WSMB evaluation 756 showed that similar results were obtained using the two methods. In contrast, the 757 distributed approach was better at simulating the SSMB. The similar performances of 758 the semi-distributed and distributed simulations during winter, but the better results for 759 the distributed simulations for summer resulted in the distributed approach providing 760 greater accuracy at the annual scale. The better results obtained for both glaciers 761 analyzed for a long time period (ASMB) using the distributed simulations suggests that 762 this approach is likely to provide more reliable results over longer periods.

763 The distributed simulation of the ELA generally showed closest agreement with 764 observations, but for certain years the semi-distributed simulations most accurately 765 reproduced the observed values. Thus, it is not possible to conclude that one approach 766 to reproducing the ELA was superior. This uncertainty may be related to the coarse 767 pixel size, which did not enable the high spatial heterogeneity of the terrain to be 768 captured. The annual ELA covers a small area of the glaciers (it represents the snow line 769 limit between snow-free and snow-covered areas), and thus the effect of spatial 770 heterogeneity is likely to be significant.

771 Overall, the distributed simulations were better at reproducing observational data. Thus,

772 distributed simulations, which better represent the spatial heterogeneity of mountain 773 areas, in general produce more accurate snowpack simulations, and are the 
The Cryosphere Discuss., https://doi.org/10.5194/tc-2017-184

Manuscript under review for journal The Cryosphere

Discussion started: 27 September 2017

(c) Author(s) 2017. CC BY 4.0 License.

recommended modeling approach. However, depending on the purpose of the simulations and the accuracy required, other factors must be considered. For instance, semi-distributed simulations have lower computing resource requirements; in this study, the distributed approach had computing requirements that were a factor of 100 greater. The accuracy of semi-distributed simulations in reproducing the snowpack evolution over large areas makes them useful in many applications.

\subsection{Future perspectives on distributed snowpack simulations}

Simulating the snowpack evolution in mountain areas is challenging. Although advances in meteorological/snowpack models and simulation approaches are improving the reproduction of observational data, inaccuracies remain. Many studies have highlighted the potential to improve snowpack modeling by assimilating observational data (Griessinger et al., 2016; Thirel et al., 2013). Satellite data enables the distribution of the snowpack over large areas to be determined, and the assimilation of such data into snowpack models has been shown to significantly improve the simulation results (Charrois et al., 2016). In distributed snowpack simulations almost direct satellite data can be assimilated, in contrast to the semi-distributed approach. Additionally, meteorological forcing models having high spatial resolution are improving simulations of the spatial pattern of meteorological variables in mountain areas (Schirmer and Jamieson, 2015; Vionnet et al., 2016; Weusthoff et al., 2010). This will improve snowpack simulations (Förster et al., 2014; Quéno et al., 2016), even though it is challenging to combine high resolution numerical weather prediction models with precipitation measurements assimilation in analysis systems. Interest in distributed snowpack simulations will be enhanced when reliable high spatial resolution meteorological forcing data are available, as only this simulation approach can take full advantage of such data. Further research is needed on parameterizing small scale snowpack processes for incorporation in modeling, including wind driven snow transport (Dadic et al., 2010b; Winstral et al., 2012), avalanche snow redistribution (Bernhardt and Schulz, 2010), and topographic control on snow distribution (Revuelto et al.,. 2016a). Inclusion of these processes, together with the incorporation of reliable meteorological forcing and satellite data, assimilation will improve the accuracy of snowpack simulations over extensive mountain areas. 
The Cryosphere Discuss., https://doi.org/10.5194/tc-2017-184

Manuscript under review for journal The Cryosphere

Discussion started: 27 September 2017

(c) Author(s) 2017. CC BY 4.0 License.

\section{Conclusions}

806 This study provided a detailed assessment of the ability of the SAFRAN-Crocus system

807 to simulate the snow and ice dynamics in complex alpine terrain using distributed and

808 semi-distributed simulation approaches. The study was undertaken in the upper Arve

809 catchment in the western French Alps, with simulations run for the 1989-90 to the

$810 \quad 2014-15$ snow seasons.

811 A preliminary evaluation of the simulations was completed based on observations of

812 snow depth derived from five meteorological stations within the study area. This was

813 only performed using punctual snowpack simulations, to provide an initial assessment

814 of model performance over non-glaciated terrain. Despite some discrepancies between

815 observations and simulations, the model reliably reproduced the snow depth, especially

816 during melt periods.

817 In regard to the spatial scale of snowpack simulations over extended areas, the semi-

818 distributed and distributed simulations were compared using the same observation

819 datasets, including: (i) the temporal evolution of the snow-covered area based on data

820 from the MODIS sensor; (ii) measurements of surface mass balance of glaciers within

821 the upper Arve catchment; and (iii) observational data on the annual evolution of the

822 equilibrium-line altitude for the various glaciers considered.

823 Both simulation methods accurately reproduced the evolution of the SCA during

824 accumulation events, as they relied on the same meteorological forcing data. For the

825 winter to early spring period, when the study area is almost completely covered by

826 snow, there was little difference between the two approaches. However, for the melt

827 period the distributed simulations better reproduced the observations.

828 The simulations for low elevations and elevations > 2700 m.a.s.l. underestimated

829 (negative underestimation in low elevations and positive in high) the observed SMB.

830 Nevertheless, the results of both simulations were in close agreement with observations

831 at mid-elevation areas, and adequately reproduced the observed annual SMB at all

832 elevations. Overall, the distributed simulations yielded better results.

833 Based on comparison with ELA data obtained from various satellites at the end of

834 summer, the SAFRAN-Crocus accurately reproduced the inter-annual variability of the

835 snowpack over glaciated areas. However, differences between observations and

836 simulations were evident, particularly for the smallest glacierized areas, where the

837 spatial resolution of the simulations did not enable the high spatial variability of the 
The Cryosphere Discuss., https://doi.org/10.5194/tc-2017-184

Manuscript under review for journal The Cryosphere

Discussion started: 27 September 2017

(C) Author(s) 2017. CC BY 4.0 License.

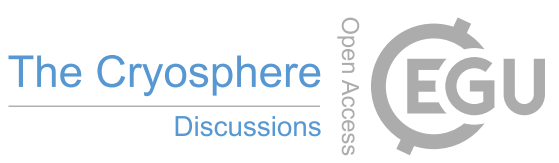

(c) $\underset{\mathrm{BY}}{(i)}$

838 topography to be included. In addition, based on the ELA evaluation, the distributed

839 approach was slightly better at reproducing the snowpack dynamics.

840 Overall, the results of this study demonstrated that distributed simulations were better at

841 reproducing snowpack dynamics in the alpine terrain of our study area. Distributed

842 simulations take account of the specific topographic characteristics of each pixel and

843 also the effects of terrain shadowing by surrounding areas. Inclusion of these two effects

844 over long time periods led to better results being obtained using the distributed

845 approach. Distributed simulations will facilitate incorporation of the latest snowpack

846 modeling advances, including assimilation of satellite data and the use of higher spatial

847 resolution meteorological forcing models. 
The Cryosphere Discuss., https://doi.org/10.5194/tc-2017-184

Manuscript under review for journal The Cryosphere

Discussion started: 27 September 2017

(C) Author(s) 2017. CC BY 4.0 License.

849 This study was funded by Syndicat mixte d'aménagement de l'Arve et de 850 ses abords (SM3A), Communauté de Communes de la Vallée de Chamonix Mont-Blanc 851 and Fondation Terre Solidaire in the framework of the Programme 852 d'Action de Prévention des Inondations (PAPI). We thank Glacioclim

853 (https://glacioclim.osug.fr) for generating the glacier surface mass balance database 854 used in the study. J. Revuelto benefited from a grant within the above-cited PAPI 855 project and is now supported by a Post-doctoral Fellowship of the AXA research found 856 (le Post-Doctorant Jesús Revuelto est bénéficiaire d'une bourse postdoctorale du Fonds

857 AXA pour la Recherchem Ref: CNRM 3.2.01/17). IGE and CNRM/CEN are part of 858 Labex OSUG@2020. 
The Cryosphere Discuss., https://doi.org/10.5194/tc-2017-184

Manuscript under review for journal The Cryosphere

Discussion started: 27 September 2017

(c) Author(s) 2017. CC BY 4.0 License.

859

860

861

862

863

864

865

866

867

868

869

870

871

872

873

874

875

876

\section{References}

Avanzi, F., De Michele, C., Morin, S., Carmagnola, C.M., Ghezzi, A., and Lejeune, Y. (2016). Model complexity and data requirements in snow hydrology: seeking a balance in practical applications. Hydrol. Process. 30, 2106-2118.

Bartelt, P., and Lehning, M. (2002). A physical SNOWPACK model for the Swiss avalanche warning: Part I: numerical model. Cold Reg. Sci. Technol. 35, 123-145.

Barnett, T.P., Adam, J.C., and Lettenmaier, D.P. (2005). Potential impacts of a warming climate on water availability in snow-dominated regions. Nature 438, 303-309.

Bartelt, P., and Lehning, M. (2002). A physical SNOWPACK model for the Swiss avalanche warning: Part I: numerical model. Cold Reg. Sci. Technol. 35, 123-145.

Berghuijs, W.R., Woods, R.A., Hutton, C.J., and Sivapalan, M. (2016). Dominant flood generating mechanisms across the United States. Geophys. Res. Lett. 43, 2016GL068070.

Bernhardt, M., and Schulz, K. (2010). SnowSlide: A simple routine for calculating gravitational snow transport. Geophys. Res. Lett. 37, L11502.

löschl, G., and Sivapalan, M. (1995). Scale issues in hydrological modelling: A review. Hydrol. Process. 9, 251-290.

Braithwaite, R.J. (1984). Short Notes: Can the Mass Balance of a Glacier be Estimated from its Equilibrium-Line Altitude? J. Glaciol. 30, 364-368.

Braun, L.N., Brun, E., Durand, Y., Martin, E., and Tourasse, P. (1994). Simulation of discharge using different methods of meteorological data distibution, basin discretization and snow modelling. Nord. Hydrol. 25, 129-144.

Brun, E., David, P., Sudul, M., and Brunot, G. (1992). A numerical model to simulate snow-cover stratigraphy for operational avalanche forecasting. J. Glaciol. 38, 13-22.

Carpenter, T.M., and Georgakakos, K.P. (2006). Intercomparison of lumped versus distributed hydrologic model ensemble simulations on operational forecast scales. J. Hydrol. 329, 174-185.

Charrois, L., Dumont, M., Sirguey, P., Morin, S., Lafaysse, M., and Karbou, F. (2013).

Comparing different MODIS snow products with distributed distributed simulation of 
The Cryosphere Discuss., https://doi.org/10.5194/tc-2017-184

Manuscript under review for journal The Cryosphere

Discussion started: 27 September 2017

(c) Author(s) 2017. CC BY 4.0 License. a detailed snowpack model. The Cryosphere 10, 1021-1038.

893 Christen, M., Kowalski, J., and Bartelt, P. (2010). RAMMS: Numerical simulation of dense snow avalanches in three-dimensional terrain. Cold Reg. Sci. Technol. 63, 1-14. Courtier P, Thépaut J-N, Hollingsworth A. 1994. A strategy for operational implementation of 4D-Var using an incremental approach. Q. J. R. Meteorol. Soc. 120 $1367-1388$

898 Cuffey, K.M., and Paterson, W.S.B. (2010). The Physics of Glaciers (Academic Press 899 Inc, Amsterdam (NL)).

900 Dadic, R., Mott, R., Lehning, M., and Burlando, P. (2010a). Wind influence on snow 901 depth distribution and accumulation over glaciers. J. Geophys. Res. Earth Surf. 115, 902 F01012.

903 Dadic, R., Mott, R., Lehning, M., and Burlando, P. (2010b). Parameterization for wind904 induced preferential deposition of snow. Hydrol. Process. 24, 1994-2006.

905 DeBeer, C.M., and Pomeroy, J.W. (2009). Modelling snow melt and snowcover 906 depletion in a small alpine cirque, Canadian Rocky Mountains. Hydrol. Process. 23, 907 2584-2599.

908 Decharme, B., Boone, A., Delire, C., and Noilhan, J. (2011). Local evaluation of the 909 Interaction between Soil Biosphere Atmosphere soil multilayer diffusion scheme using 910 four pedotransfer functions. J. Geophys. Res. Atmospheres 116, D20126.

911 Dedieu, J.-P., Carlson, B.Z., Bigot, S., Sirguey, P., Vionnet, V., and Choler, P. (2016). 912 On the Importance of High-Resolution Time Series of Optical Imagery for Quantifying 913 the Effects of Snow Cover Duration on Alpine Plant Habitat. Remote Sens. 8, 481.

914 Dubuisson, M.P., and Jain, A.K. (1994). A modified Hausdorff Distance for Object 915 Matching. Proc. Int. Conf. Pattern Recognit. Jerus. Isr. 566-568. 
The Cryosphere Discuss., https://doi.org/10.5194/tc-2017-184

Manuscript under review for journal The Cryosphere

Discussion started: 27 September 2017

(c) Author(s) 2017. CC BY 4.0 License.

916 Dumont, M., Durand, Y., Arnaud, Y., and Six, D. (2012a). Variational assimilation of

917 albedo in a snowpack model and reconstruction of the spatial mass-balance distribution

918 of an alpine glacier. J. Glaciol. 58, 151-164.

919 Dumont, M., Gardelle, J., Sirguey, P., Guillot, A., Six, D., Rabatel, A., and Arnaud, Y.

920 (2012b). Linking glacier annual mass balance and glacier albedo retrieved from MODIS

921 data. The Cryosphere 6, 1527-1539.

922 Durand, Y., Brun, E., Mèrindol, L., Guyomarc'h, G., Lesaffre, B., and Martin, E.

923 (1993). A meteorological estimation of relevant parameters for snow models. Ann.

924 Glaciol. 18, 65-71.

925 Durand, Y., Giraud, G., Brun, E., Merindol, L., and Martin, E. (1999). A computer-

926 based system simulating snowpack structures as a tool for regional avalanche

927 forecasting. J. Glaciol. 45, 469-484.

928 Durand, Y., Laternser, M., Giraud, G., Etchevers, P., Lesaffre, B., and Mérindol, L.

929 (2009a). Reanalysis of 44 Yr of Climate in the French Alps (1958-2002): Methodology,

930 Model Validation, Climatology, and Trends for Air Temperature and Precipitation. J.

931 Appl. Meteorol. Climatol. 48, 429-449.

932 Durand, Y., Giraud, G., Laternser, M., Etchevers, P., Mérindol, L., and Lesaffre, B.

933 (2009b). Reanalysis of 47 Years of Climate in the French Alps (1958-2005):

934 Climatology and Trends for Snow Cover. J. Appl. Meteorol. Climatol. 48, 2487-2512.

935 Egli, L., and Jonas, T. (2009). Hysteretic dynamics of seasonal snow depth distribution

936 in the Swiss Alps. Geophys. Res. Lett. 36, L02501.

937 Essery, R., and Etchevers, P. (2004). Parameter sensitivity in simulations of snowmelt.

938 J. Geophys. Res. Atmospheres 109, D20111.

939 Essery, R., Martin, E., Douville, H., Fernández, A., and Brun, E. (1999). A comparison

940 of four snow models using observations from an alpine site. Clim. Dyn. 15, 583-593.

941 Faroux, S., Kaptué Tchuenté, A.T., Roujean, J.-L., Masson, V., Martin, E., and Le

942 Moigne, P. (2013). ECOCLIMAP-II/Europe: a twofold database of ecosystems and

943 surface parameters at $1-\mathrm{km}$ resolution based on satellite information for use in land

944 surface, meteorological and climate models. Geosci. Model Dev. 6, 563-582. 
The Cryosphere Discuss., https://doi.org/10.5194/tc-2017-184

Manuscript under review for journal The Cryosphere

Discussion started: 27 September 2017

(c) Author(s) 2017. CC BY 4.0 License.

945 Fiddes, J., and Gruber, S. (2012). TopoSUB: a tool for efficient large area numerical

946 modelling in complex topography at sub-grid scales. Geosci Model Dev 5, 1245-1257.

947 Fiddes, J., and Gruber, S. (2014). TopoSCALE v.1.0: downscaling gridded climate data

948 in complex terrain. Geosci Model Dev 7, 387-405.

949 Förster, K., Meon, G., Marke, T., and Strasser, U. (2014). Effect of meteorological

950 forcing and snow model complexity on hydrological simulations in the Sieber

951 catchment (Harz Mountains, Germany). Hydrol. Earth Syst. Sci. 18, 4703-4720.

952 Gaál, L., Szolgay, J., Kohnová, S., Hlavčová, K., Parajka, J., Viglione, A., Merz, R., 953 and Blöschl, G. (2015). Dependence between flood peaks and volumes: a case study on

954 climate and hydrological controls. Hydrol. Sci. J. 60, 968-984.

955 Gardent, M., Rabatel, A., Dedieu, J.-P., and Deline, P. (2014). Multitemporal glacier 956 inventory of the French Alps from the late 1960s to the late 2000s. Glob. Planet.

957 Change 120, 24-37.

958 Gascoin, S., Hagolle, O., Huc, M., Jarlan, L., Dejoux, J.-F., Szczypta, C., Marti, R., and 959 Sánchez, R. (2015). A snow cover climatology for the Pyrenees from MODIS snow 960 products. Hydrol Earth Syst Sci 19, 2337-2351.

961 Gerbaux, M., Genthon, C., Etchevers, P., Vincent, C., and Dedieu, J.P. (2005). Surface

962 mass balance of glaciers in the French Alps: distributed modeling and sensitivity to

963 climate change. J. Glaciol. 51, 561-572.

964 Griessinger, N., Seibert, J., Magnusson, J., and Jonas, T. (2016). Assessing the benefit 965 of snow data assimilation for runoff modeling in Alpine catchments. Hydrol Earth Syst 966 Sci 20, 3895-3905.

967 Grünewald, T., Schirmer, M., Mott, R., and Lehning, M. (2010). Spatial and temporal 968 variability of snow depth and ablation rates in a small mountain catchment. The 969 Cryosphere 4, 215-225.

970 Grusson, Y., Sun, X., Gascoin, S., Sauvage, S., Raghavan, S., Anctil, F., and Sáchez-

971 Pérez, J.-M. (2015). Assessing the capability of the SWAT model to simulate snow, 972 snow melt and streamflow dynamics over an alpine watershed. J. Hydrol. 531, Part 3, 973 574-588. 
The Cryosphere Discuss., https://doi.org/10.5194/tc-2017-184

Manuscript under review for journal The Cryosphere

Discussion started: 27 September 2017

(c) Author(s) 2017. CC BY 4.0 License.

974 Hall, D.K., and Riggs, G.A. (2007). Accuracy assessment of the MODIS snow product.

975 Hydrol. Process. 21, 1534-1547.

976 Hanzer, F., Helfricht, K., Marke, T., and Strasser, U. (2016). Multilevel spatiotemporal

977 validation of snow/ice mass balance and runoff modeling in glacierized catchments. The

978 Cryosphere 10, 1859-1881.

979 Hock, R. (2005). Glacier melt: a review of processes and their modelling. Prog. Phys.

980 Geogr. 29, 362-391.

981 Hood, J.L., and Hayashi, M. (2015). Characterization of snowmelt flux and

982 groundwater storage in an alpine headwater basin. J. Hydrol. 521, 482-497.

983 Klein, A.G., and Barnett, A.C. (2003). Validation of daily MODIS snow cover maps of

984 the Upper Rio Grande River Basin for the 2000-2001 snow year. Remote Sens.

985 Environ. 86, 162-176.

986 Kling, H., and Nachtnebel, H.P. (2009). A spatio-temporal comparison of water balance

987 modelling in an Alpine catchment. Hydrol. Process. 23, 997-1009.

988 Lafaysse, M., Morin, S., Coléou, C., Vernay, M., Serça, D., Besson, F., Willemet, J.M.,

989 Giraud, G., and Durand, Y. (2013). Towards a new chain of models for avalanche

990 hazard forecasting in French mountain ranges, including low altitude mountains. Int.

991 Snow Sci. Workshop Grenoble-Chamonix Mont-Blanc.

992 Lehning, M., Völksch, I., Gustafsson, D., Nguyen, T.A., Stähli, M., and Zappa, M.

993 (2006). ALPINE3D: a detailed model of mountain surface processes and its application

994 to snow hydrology. Hydrol. Process. 20, 2111-2128.

995 Lehning, M., Grünewald, T., and Schirmer, M. (2011). Mountain snow distribution

996 governed by an altitudinal gradient and terrain roughness. Geophys. Res. Lett. 38,

997 L19504.

998 Lejeune, Y., Bertrand, J.-M., Wagnon, P., and Morin, S. (2013). A physically based

999 model of the year-round surface energy and mass balance of debris-covered glaciers. J.

1000 Glaciol. 59, 327-344.

1001 Li, H., Xu, C.-Y., and Beldring, S. (2015). How much can we gain with increasing

1002 model complexity with the same model concepts? J. Hydrol. 527, 858-871. 
The Cryosphere Discuss., https://doi.org/10.5194/tc-2017-184

Manuscript under review for journal The Cryosphere

Discussion started: 27 September 2017

(c) Author(s) 2017. CC BY 4.0 License.

1003 Liston, G.E., Haehnel, R.B., Sturm, M., Hiemstra, C.A., Berezovskaya, S., and Tabler,

1004 R.D. (2007). Simulating complex snow distributions in windy environments using

1005 SnowTran-3D. J. Glaciol. 53, 241-256.

1006 López-Moreno, J.I., and García-Ruiz, J.M. (2004). Influence of snow accumulation and

1007 snowmelt on streamflow in the central Spanish Pyrenees / Influence de l'accumulation

1008 et de la fonte de la neige sur les écoulements dans les Pyrénées centrales espagnoles.

1009 Hydrol. Sci. J. 49, 787-802.

1010 López-Moreno, J.I., Fassnacht, S.R., Heath, J.T., Musselman, K.N., Revuelto, J., 1011 Latron, J., Morán-Tejeda, E., and Jonas, T. (2013). Small scale spatial variability of 1012 snow density and depth over complex alpine terrain: Implications for estimating snow 1013 water equivalent. Adv. Water Resour. 55, 40-52.

1014 López-Moreno, J.I., Revuelto, J., Rico, I., Chueca-Cía, J., Julián, A., Serreta, A., 1015 Serrano, E., Vicente-Serrano, S.M., Azorin-Molina, C., Alonso-González, E., et al. 1016 (2016). Thinning of the Monte Perdido Glacier in the Spanish Pyrenees since 1981. The 1017 Cryosphere 10, 681-694.

1018 Masson, V., Le Moigne, P., Martin, E., Faroux, S., Alias, A., Alkama, R., Belamari, S.,

1019 Barbu, A., Boone, A., Bouyssel, F., et al. (2013). The SURFEXv7.2 land and ocean 1020 surface platform for coupled or offline simulation of earth surface variables and fluxes.

1021 Geosci Model Dev 6, 929-960.

1022 McCreight, J.L., Slater, A.G., Marshall, H.P., and Rajagopalan, B. (2012). Inference 1023 and uncertainty of snow depth spatial distribution at the kilometre scale in the Colorado 1024 Rocky Mountains: The effects of sample size, random sampling, predictor quality, and 1025 validation procedures. Hydrological Processes. 28 (3), 933-957.

1026 Meusburger, K., Leitinger, G., Mabit, L., Mueller, M.H., Walter, A., and Alewell, C. 1027 (2014). Soil erosion by snow gliding - a first quantification attempt in a subalpine area 1028 in Switzerland. Hydrol. Earth Syst. Sci. 18, 3763-3775.

1029 Mott, R., Schirmer, M., Bavay, M., Grünewald, T., and Lehning, M. (2010). 1030 Understanding snow-transport processes shaping the mountain snow-cover. The 1031 Cryosphere 4, 545-559.

1032 Nester, T., Kirnbauer, R., Parajka, J., and Blöschl, G. (2012). Evaluating the snow 1033 component of a flood forecasting model. Hydrol. Res. 43, 762-779. 
The Cryosphere Discuss., https://doi.org/10.5194/tc-2017-184

Manuscript under review for journal The Cryosphere

Discussion started: 27 September 2017

(c) Author(s) 2017. CC BY 4.0 License.

1034 Oreiller, M., Nadeau, D.F., Minville, M., and Rousseau, A.N. (2014). Modelling snow

1035 water equivalent and spring runoff in a boreal watershed, James Bay, Canada. Hydrol.

1036 Process. 28, 5991-6005.

1037 Orth, R., Staudinger, M., Seneviratne, S.I., Seibert, J., and Zappa, M. (2015). Does

1038 model performance improve with complexity? A case study with three hydrological

1039 models. J. Hydrol. 523, 147-159.

1040 Parajka, J., and Blöschl, G. (2008). Spatio-temporal combination of MODIS images 1041 potential for snow cover mapping. Water Resour. Res. 44 (3).

1042 Pomeroy, J., Essery, R., and Toth, B. (2004). Implications of spatial distributions of 1043 snow mass and melt rate for snow-cover depletion: Observations in a subarctic 1044 mountain catchment. Ann. Glaciol. 38, 195-201.

1045 Pomeroy, J., Fang, X., and Ellis, C. (2012). Sensitivity of snowmelt hydrology in 1046 Marmot Creek, Alberta, to forest cover disturbance. Hydrol. Process. 26, 1891-1904.

1047 Quéno, L., Vionnet, V., Dombrowski-Etchevers, I., Lafaysse, M., Dumont, M., and 1048 Karbou, F. (2016). Snowpack modelling in the Pyrenees driven by kilometric-resolution 1049 meteorological forecasts. The Cryosphere 10, 1571-1589.

1050 Rabatel, A., Dedieu, J.-P., and Vincent, C. (2005). Using remote-sensing data to 1051 determine equilibrium-line altitude and mass-balance time series: validation on three 1052 French glaciers, 1994-2002. J. Glaciol. 51, 539-546.

1053 Rabatel, A., Letréguilly, A., Dedieu, J.-P., and Eckert, N. (2013). Changes in glacier 1054 equilibrium-line altitude in the western Alps from 1984 to 2010: evaluation by remote 1055 sensing and modeling of the morpho-topographic and climate controls. The Cryosphere $10567,1455-1471$.

1057 Rabatel, A., Dedieu, J.-P., and Vincent, C. (2016). Spatio-temporal changes in glacier1058 wide mass balance quantified by optical remote-sensing on 30 glaciers in the French 1059 Alps for the period 1983-2014. J. Glaciol., 62 (236), 1153-1166. doi: $1060 \quad 10.1017 /$ jog.2016.113.

1061 Raleigh, M.S., Lundquist, J.D., and Clark, M.P. (2015). Exploring the impact of forcing 1062 error characteristics on physically based snow simulations within a global sensitivity 1063 analysis framework. Hydrol Earth Syst Sci 19, 3153-3179. 
The Cryosphere Discuss., https://doi.org/10.5194/tc-2017-184

Manuscript under review for journal The Cryosphere

Discussion started: 27 September 2017

(c) Author(s) 2017. CC BY 4.0 License.

1064 Réveillet, M., Vincent, C., Six, D., and Rabatel, A. (2017). Which empirical model is 1065 best suited to simulating glacier mass balances? J. Glaciol., 63 (237), 39-54. doi: $1066 \quad 10.1017 /$ jog.2016.110.

1067 Réveillet, M., Six, D., Vincent, C., Rabatel., A., Dumont, M., Lafaysse, M., Morin, S., 1068 Vionnet, V., Litt, M.(submitted). Relative performance of empirical and physical 1069 models in assessing seasonal and annual glacier surface mass balance in the French 1070 Alps. The Cryosphere.

1071 Revuelto, J., López-Moreno, J.I., Azorin-Molina, C., and Vicente-Serrano, S.M. (2014). 1072 Topographic control of snowpack distribution in a small catchment in the central 1073 Spanish Pyrenees: Intra- and inter-annual persistence. Cryosphere 8, 1989-2006.

1074 Revuelto, J., Vionnet, V., López-Moreno, J.I., Lafaysse, M., and Morin, S. (2016a).

1075 Combining snowpack modeling and terrestrial laser scanner observations improves the 1076 simulation of small scale snow dynamics. J. Hydrol. 291-307.

1077 Revuelto, J., Jonas, T., and López-Moreno, J.-I. (2016b). Backward snow depth 1078 reconstruction at high spatial resolution based on time-lapse photography. Hydrol. 1079 Process. 30, 2976-2990.

1080 Seity, Y., Brousseau, P., Malardel, S., Hello, G., Bénard, P., Bouttier, F., Lac, C., and 1081 Masson, V. (2010). The AROME-France Convective-Scale Operational Model. Mon. 1082 Weather Rev. 139, 976-991.

1083 Schirmer, M., and Jamieson, B. (2015). Verification of analysed and forecasted winter 1084 precipitation in complex terrain. The Cryosphere 9, 587-601.

1085 Schirmer, M., Wirz, V., Clifton, A., and Lehning, M. (2011). Persistence in intra-annual 1086 snow depth distribution: 1.Measurements and topographic control. Water Resour. Res. 1087 47, W09516.

1088 Schön, P., Prokop, A., Vionnet, V., Guyomarc'h, G., Naaim-Bouvet, F., and Heiser, M.

1089 (2015). Improving a terrain-based parameter for the assessment of snow depths with 1090 TLS data in the Col du Lac Blanc area. Cold Reg. Sci. Technol. 114, 15-26.

1091 Schweizer, J., Kronholm, K., Jamieson, J.B., and Birkeland, K.W. (2008). Review of

1092 spatial variability of snowpack properties and its importance for avalanche formation.

1093 Cold Reg. Sci. Technol. 51, 253-272. 
The Cryosphere Discuss., https://doi.org/10.5194/tc-2017-184

Manuscript under review for journal The Cryosphere

Discussion started: 27 September 2017

(c) Author(s) 2017. CC BY 4.0 License.

1094 Scipión, D.E., Mott, R., Lehning, M., Schneebeli, M., and Berne, A. (2013). Seasonal

1095 small-scale spatial variability in alpine snowfall and snow accumulation. Water Resour.

1096 Res. 49, 1446-1457.

1097 Seidel, F.C., Rittger, K., Skiles, S.M., Molotch, N.P., and Painter, T.H. (2016). Case

1098 study of spatial and temporal variability of snow cover, grain size, albedo and radiative

1099 forcing in the Sierra Nevada and Rocky Mountain snowpack derived from imaging

1100 spectroscopy. The Cryosphere 10, 1229-1244.

1101 Seyfried, M.S., and Wilcox, B.P. (1995). Scale and the Nature of Spatial Variability:

1102 Field Examples Having Implications for Hydrologic Modeling. Water Resour. Res. 31, 1103 173-184.

1104 Sirguey, P., Mathieu, R., Arnaud, Y., Kahn, M.M., and Chanussot, J. (2008). Improving

1105 MODIS spatial resolution for snow mapping using wavelet fusion and ARSIS concept.

1106 IEEE Geosci. Remote Sens. Lett. 5, 78-82.

1107 Sirguey, P., Mathieu, R., and Arnaud, Y. (2009). Subpixel monitoring of the seasonal 1108 snow cover with MODIS at $250 \mathrm{~m}$ spatial resolution in the Southern Alps of New

1109 Zealand: Methodology and accuracy assessment. Remote Sens. Environ. 113, 160-181.

1110 Six, D., and Vincent, C. (2014). Sensitivity of mass balance and equilibrium-line 1111 altitude to climate change in the French Alps. J. Glaciol. 60, 867-878.

1112 Sold, L., Huss, M., Hoelzle, M., Andereggen, H., Joerg, P.C., and Zemp, M. (2013).

1113 Methodological approaches to infer end-of-winter snow distribution on alpine glaciers.

1114 1047-1059.

1115 Sturm, M., and Wagner, A.M. (2010). Using repeated patterns in snow distribution

1116 modeling: An Arctic example. Water Resour. Res. 46, W12549.

1117 Tacnet, J.-M., Dezert, J., Curt, C., Batton-Hubert, M., and Chojnacki, E. (2014). How to

1118 manage natural risks in mountain areas in a context of imperfect information? New

1119 frameworks and paradigms for expert assessments and decision-making. Environ. Syst.

1120 Decis. 34, 288-311.

1121 Thirel, G., Salamon, P., Burek, P., and Kalas, M. (2013). Assimilation of MODIS snow

1122 cover area data in a distributed hydrological model using the particle filter. Remote

1123 Sens. 5, 5825-5850. 
The Cryosphere Discuss., https://doi.org/10.5194/tc-2017-184

Manuscript under review for journal The Cryosphere

Discussion started: 27 September 2017

(c) Author(s) 2017. CC BY 4.0 License.

1124 Trujillo, E., Ramírez, J.A., and Elder, K.J. (2007). Topographic, meteorologic, and

1125 canopy controls on the scaling characteristics of the spatial distribution of snow depth

1126 fields. Water Resour. Res. 43, W07409.

1127 Viani, A., Condom, T., Vincent, C., Rabatel, A., Bacchi, A., Sicart, J.E., Revuelto, J.,

1128 Six, D., and Zin, I. (submitted). Glacier-wide summer surface mass balance

1129 reconstruction: hydrological balance applied on Argentière and Mer de Glace drainage

1130 basins (Mont Blanc, France). Journal of Glaciology.

1131 Vionnet, V., Brun, E., Morin, S., Boone, A., Faroux, S., Le Moigne, P., Martin, E., and

1132 Willemet, J.-M. (2012). The detailed snowpack scheme Crocus and its implementation

1133 in SURFEX v7.2. Geosci. Model Dev. 5, 773-791.

1134 Vionnet, V., Martin, E., Masson, V., Guyomarc'h, G., Naaim-Bouvet, F., Prokop, A.,

1135 Durand, Y., and Lac, C. (2013). Simulation of wind-induced snow transport in alpine

1136 terrain using a fully coupled snowpack/atmosphere model. Cryosphere Discuss. 7,

1137 2191-2245.

1138 Vionnet, V., Martin, E., Masson, V., Guyomarc'h, G., Naaim-Bouvet, F., Prokop, A.,

1139 Durand, Y., and Lac, C. (2014). Simulation of wind-induced snow transport and

1140 sublimation in alpine terrain using a fully coupled snowpack/atmosphere model. The

1141 Cryosphere 8, 395-415.

1142 Vionnet, V., Dombrowski-Etchevers, I., Lafaysse, M., Quéno, L., Seity, Y., and Bazile,

1143 E. (2016). Numerical Weather Forecasts at Kilometer Scale in the French Alps:

1144 Evaluation and Application for Snowpack Modeling. J. Hydrometeorol. 17, 2591-2614.

1145 Viviroli, D., Dürr, H.H., Messerli, B., Meybeck, M., and Weingartner, R. (2007).

1146 Mountains of the world, water towers for humanity: Typology, mapping, and global

1147 significance. Water Resour. Res. 43, W07447.

1148 Weusthoff, T., Ament, F., Arpagaus, M., and Rotach, M.W. (2010). Assessing the

1149 Benefits of Convection-Permitting Models by Neighborhood Verification: Examples

1150 from MAP D-PHASE. Mon. Weather Rev. 138, 3418-3433.

1151 Winstral, A., Marks, D., and Gurney, R. (2012). Simulating wind-affected snow

1152 accumulations at catchment to basin scales. Adv. Water Resour. 55, 64-79 
The Cryosphere Discuss., https://doi.org/10.5194/tc-2017-184

Manuscript under review for journal The Cryosphere

Discussion started: 27 September 2017

(c) Author(s) 2017. CC BY 4.0 License.

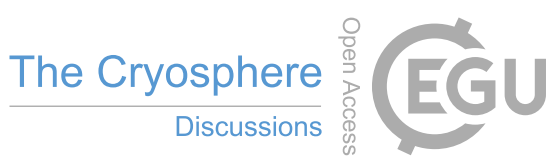

(c) (i)

1153 Wipf, S., Stoeckli, V., and Bebi, P. (2009). Winter climate change in alpine tundra:

1154 plant responses to changes in snow depth and snowmelt timing. Clim. Change 94, 105-

1155121. 
The Cryosphere Discuss., https://doi.org/10.5194/tc-2017-184

Manuscript under review for journal The Cryosphere

Discussion started: 27 September 2017

(c) Author(s) 2017. CC BY 4.0 License.

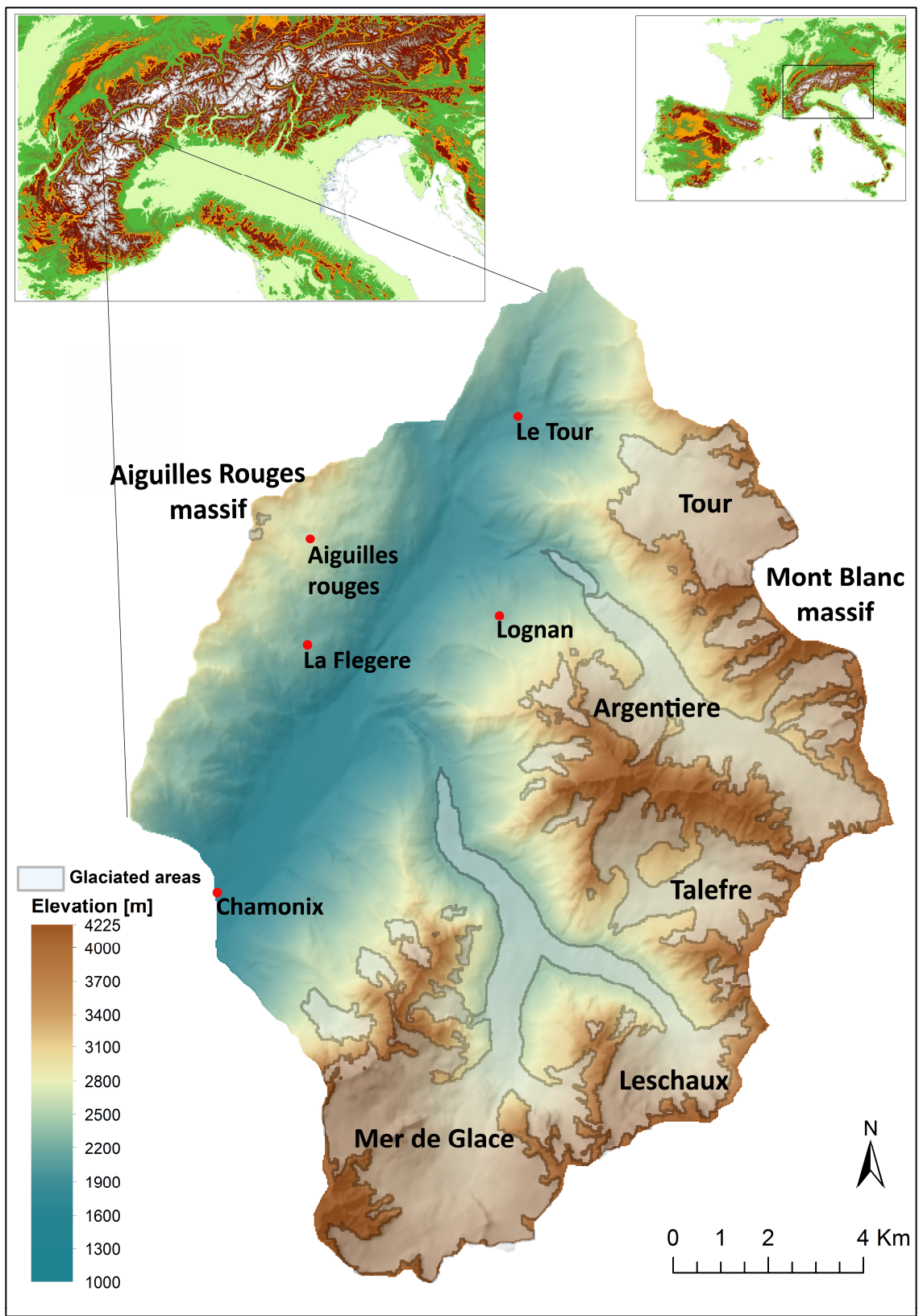

Figure 1: Upper Arve catchment study area. The white shaded area shows the extent of the glaciers in 2012 (Gardent et al., 2014). The inner maps show various magnifications of the Alps and the location of the Arve valley within the mountain range. The red points show the position of the five Météo-France stations located in the study area. 
The Cryosphere Discuss., https://doi.org/10.5194/tc-2017-184

Manuscript under review for journal The Cryosphere

Discussion started: 27 September 2017

(c) Author(s) 2017. CC BY 4.0 License.

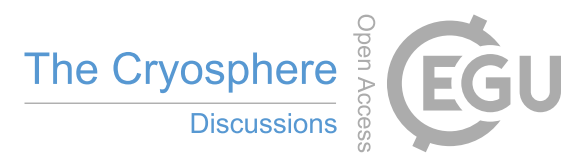

(c) (i)

1163

1164

1165

1166

1167

1168

1169

1170

1171

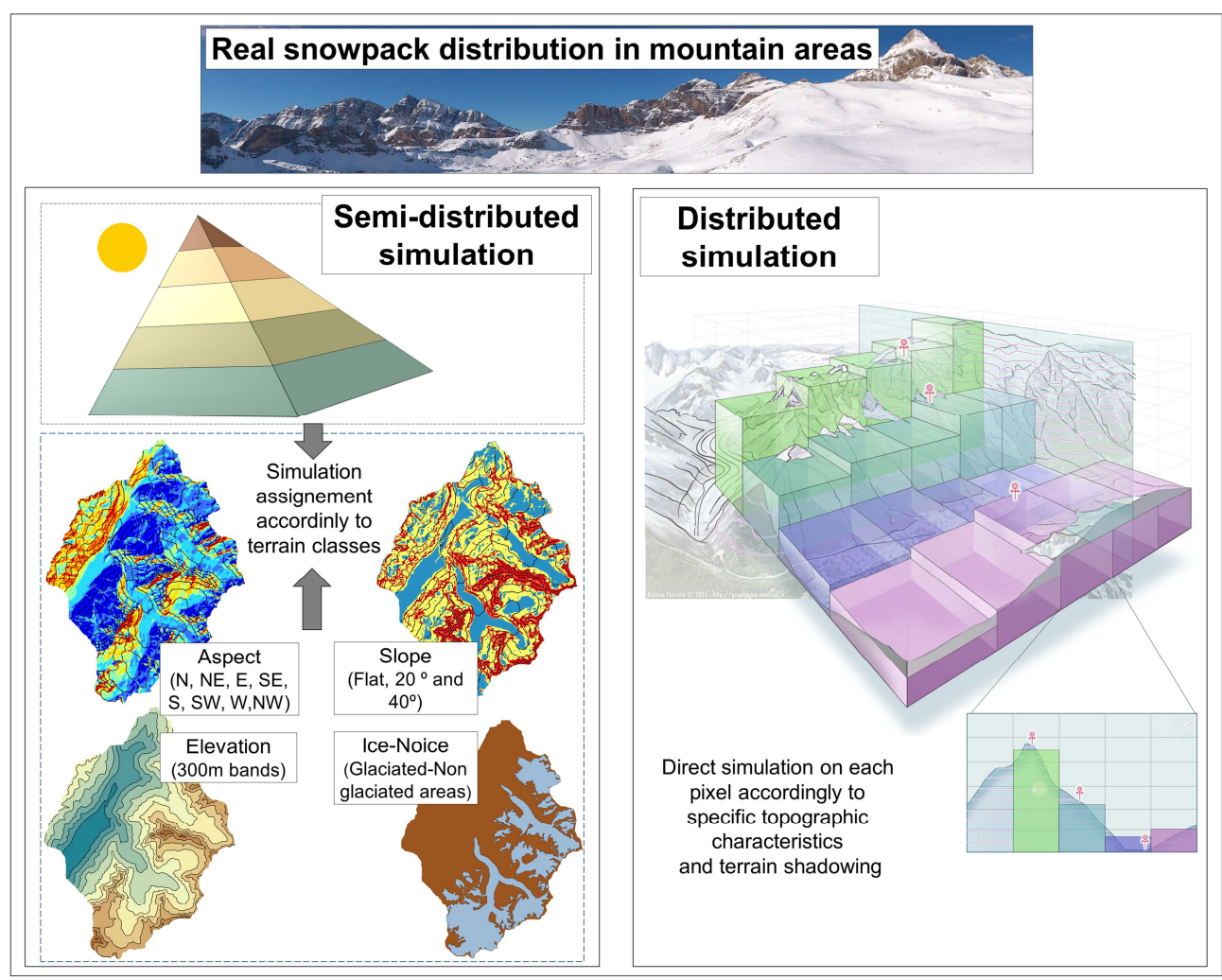

Figure 2: Schematic representation of the approaches used to account for mountain spatial heterogeneity when simulating snowpack dynamics.
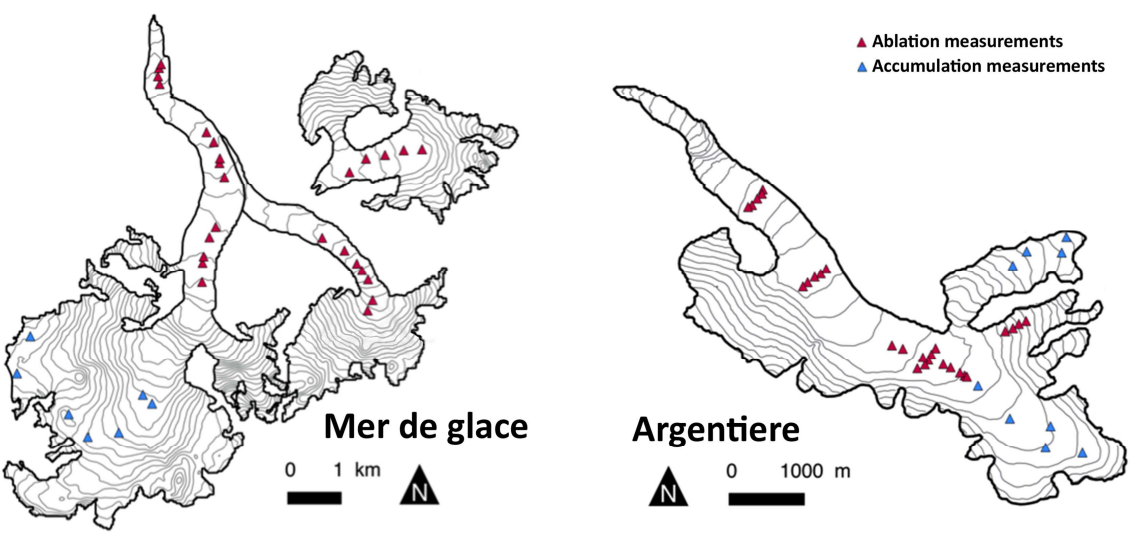

Figure 3: Glacier SMB measurement locations for ablation and accumulation areas in the Mer de Glace and Argentière glaciers. 
The Cryosphere Discuss., https://doi.org/10.5194/tc-2017-184

Manuscript under review for journal The Cryosphere

Discussion started: 27 September 2017

(c) Author(s) 2017. CC BY 4.0 License.
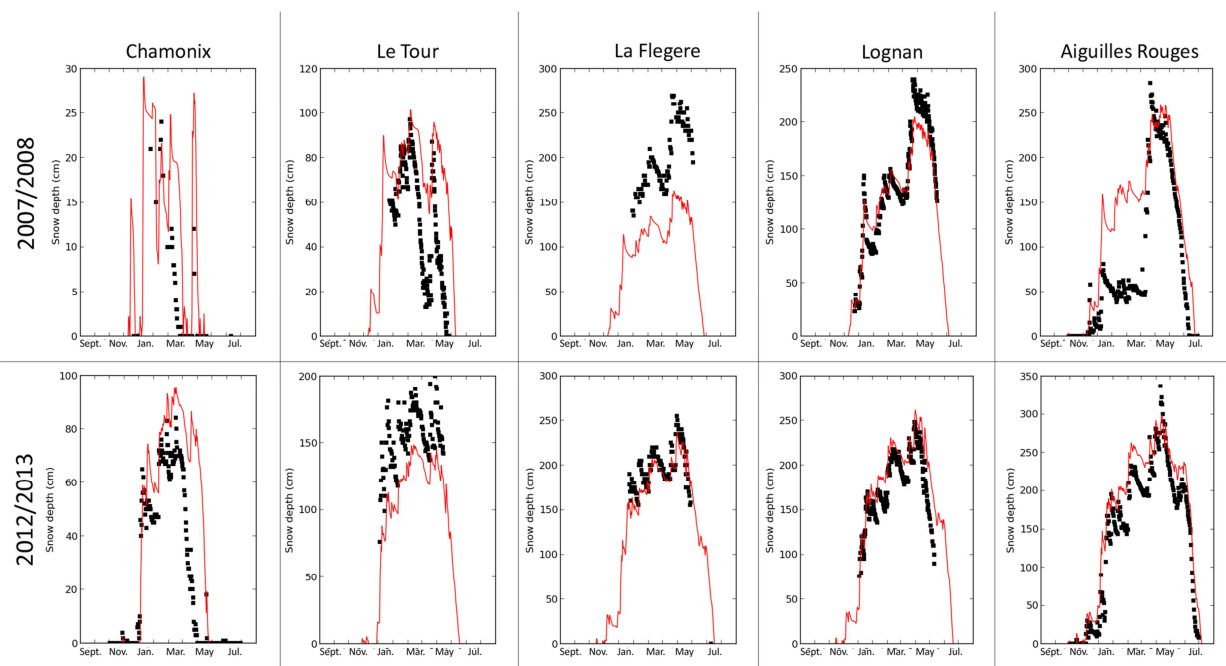

Figure 4: Observed (black squares) and simulated (red lines) snow depth evolution for the 2007-08 (upper panel) and 2012-13 (bottom panel) snow seasons. The elevations of the stations are: Chamonix: 1025 m.a.s.l.; Le Tour: 1470 m.a.s.l.; La Flegere: 1850 m.a.s.l.; Lognan: 1970 m.a.s.l.; and Aiguilles Rouges: 2365 m.a.s.l.

$24^{\text {th }}$ July 2008
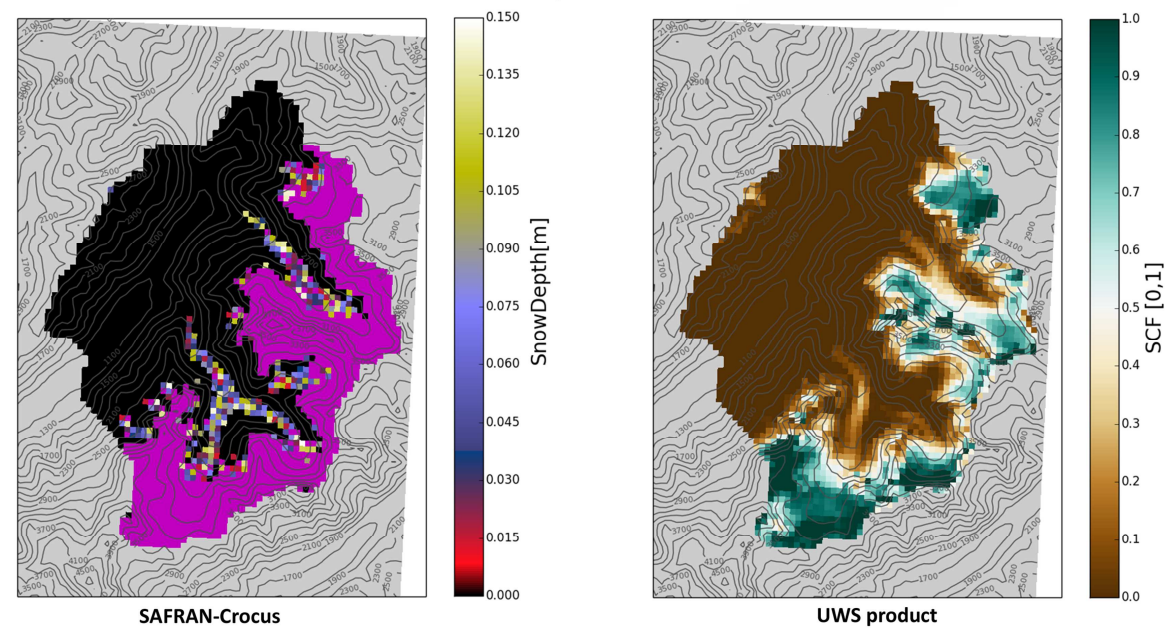

Figure 5: Spatial distribution of the UWS MODImLab product (equivalent to the SCA distribution), and the simulated snow depth obtained using the distributed approach (the purple color shows the snow depth values exceeding the $0.15 \mathrm{~m}$ threshold) for 24 July 2008. 
The Cryosphere Discuss., https://doi.org/10.5194/tc-2017-184

Manuscript under review for journal The Cryosphere

Discussion started: 27 September 2017

(c) Author(s) 2017. CC BY 4.0 License.

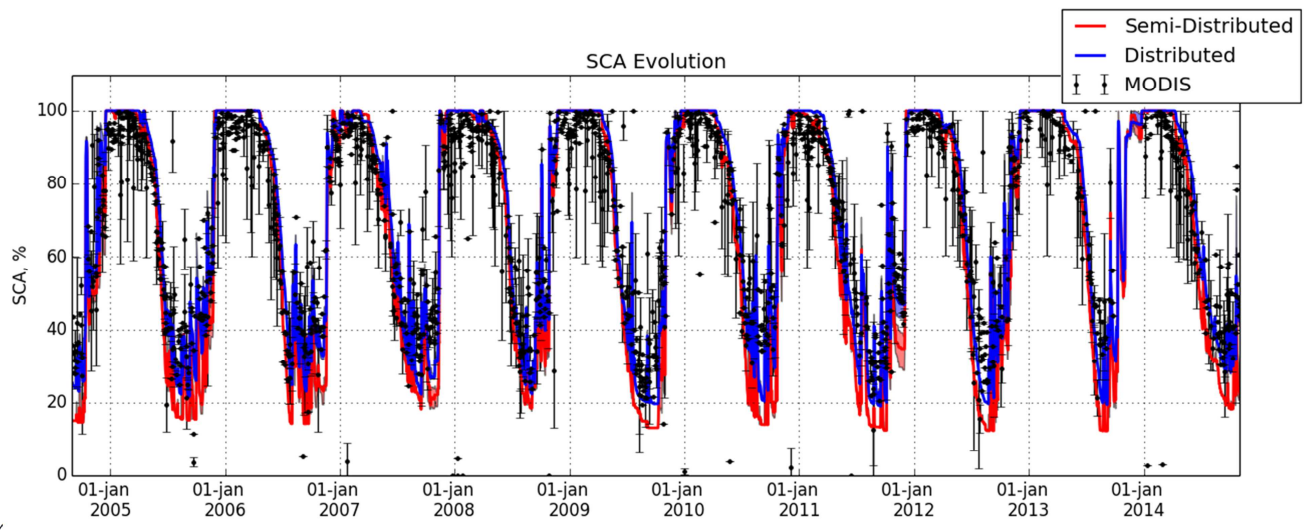

118

1185 Figure 6: Temporal evolution of the SCA (2004-2014) based on semi-distributed and

1186 distributed simulations and MODIS sensor observations. The vertical bars associated

1187 with the MODIS observations show the uncertainty associated with cloud presence for 1188 days having $\leq 20 \%$ snow cover.

1189 
The Cryosphere Discuss., https://doi.org/10.5194/tc-2017-184

Manuscript under review for journal The Cryosphere

Discussion started: 27 September 2017

(c) Author(s) 2017. CC BY 4.0 License.
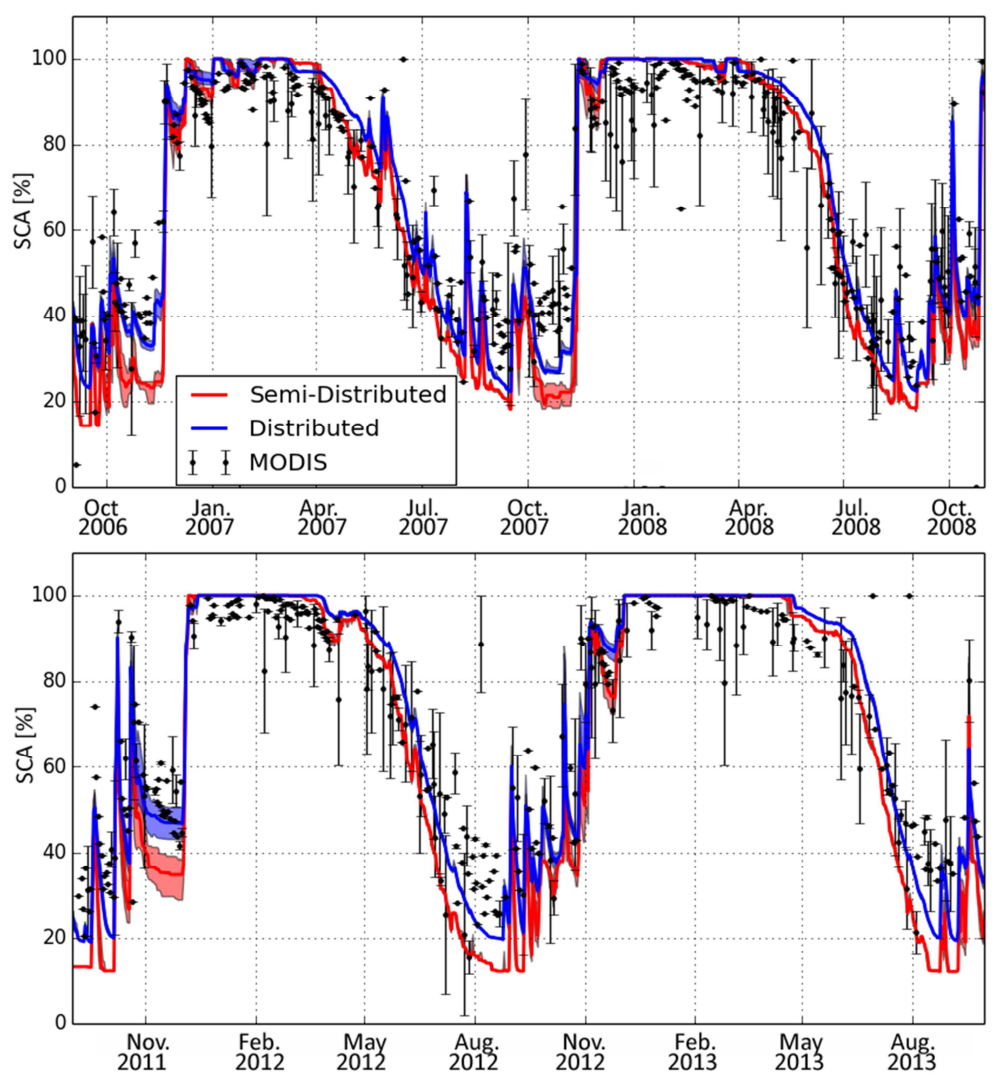

Figure 7: Observed and simulated SCA evolution for a period of low level snowpack accumulation (2006-2008; upper panel) and a period of high level snowpack accumulation (2011-2013 lower panel). The vertical bars for the MODIS observations show the uncertainty associated with cloud presence for days having $\leq 20 \%$ snow cover. Red and blue shading for the distributed and semi-distributed SCA simulations show the uncertainty associated with various snow depth thresholds for determining whether a pixel was snow covered. The lower limit of the shading represents the SCA evolution for a $0.1 \mathrm{~m}$ threshold, the upper limit of the shading represents a $0.2 \mathrm{~m}$ snow depth threshold, and the middle line represents a $0.15 \mathrm{~m}$ snow depth threshold. 
The Cryosphere Discuss., https://doi.org/10.5194/tc-2017-184

Manuscript under review for journal The Cryosphere

Discussion started: 27 September 2017

(c) Author(s) 2017. CC BY 4.0 License.
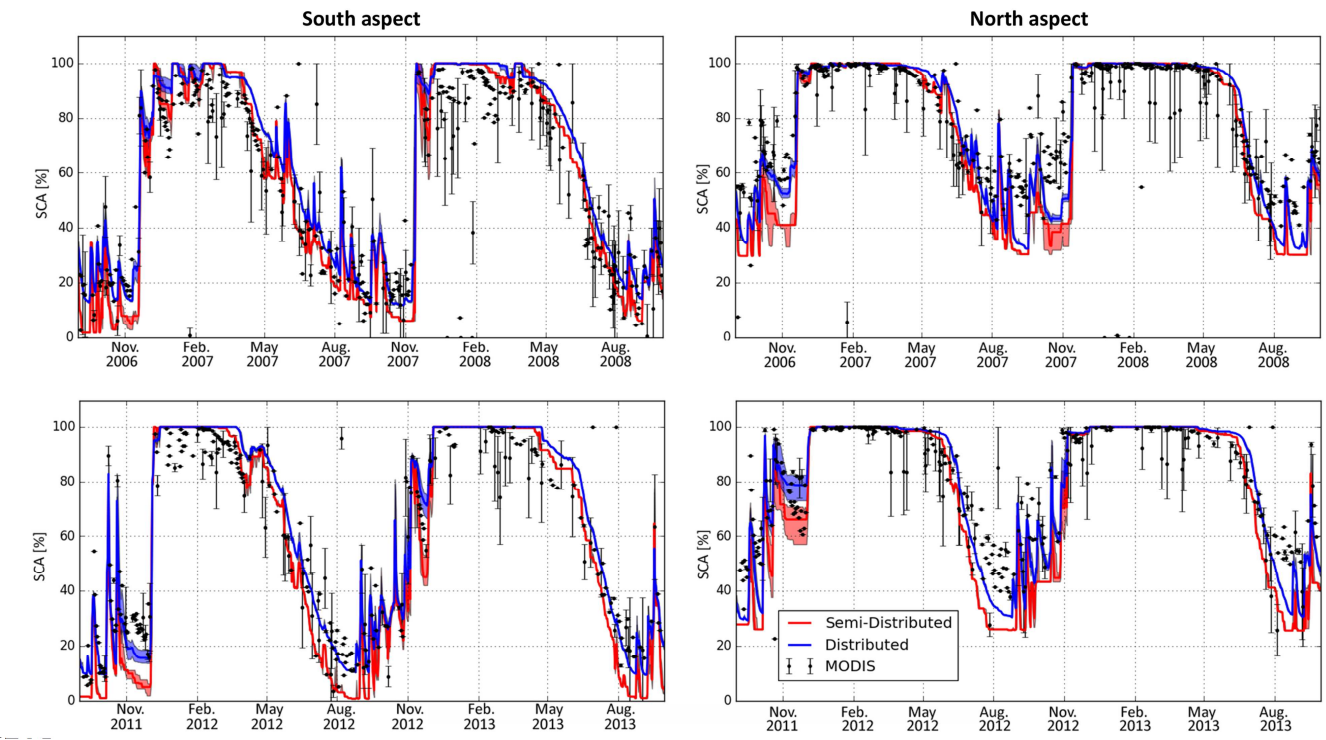

1202 Figure 8: Evolution of the SCA in relation to north and south aspect for the 2006-2008 (upper panel; low level of snowpack accumulation) and 2011-2013 (lower panel; high level of snowpack accumulation) snow seasons. Vertical bars for the MODIS observations show the uncertainty associated with cloud presence for days having $\leq$ $20 \%$ snow cover. Red and blue shading for the distributed and semi-distributed SCA simulations show the uncertainty associated with various snow depth thresholds for determining whether a pixel was snow covered. The lower limit of the shading represents the SCA evolution for a $0.1 \mathrm{~m}$ threshold, the upper limit of the shading represents a $0.2 \mathrm{~m}$ snow depth threshold, and the middle line represents a $0.15 \mathrm{~m}$ snow depth threshold.
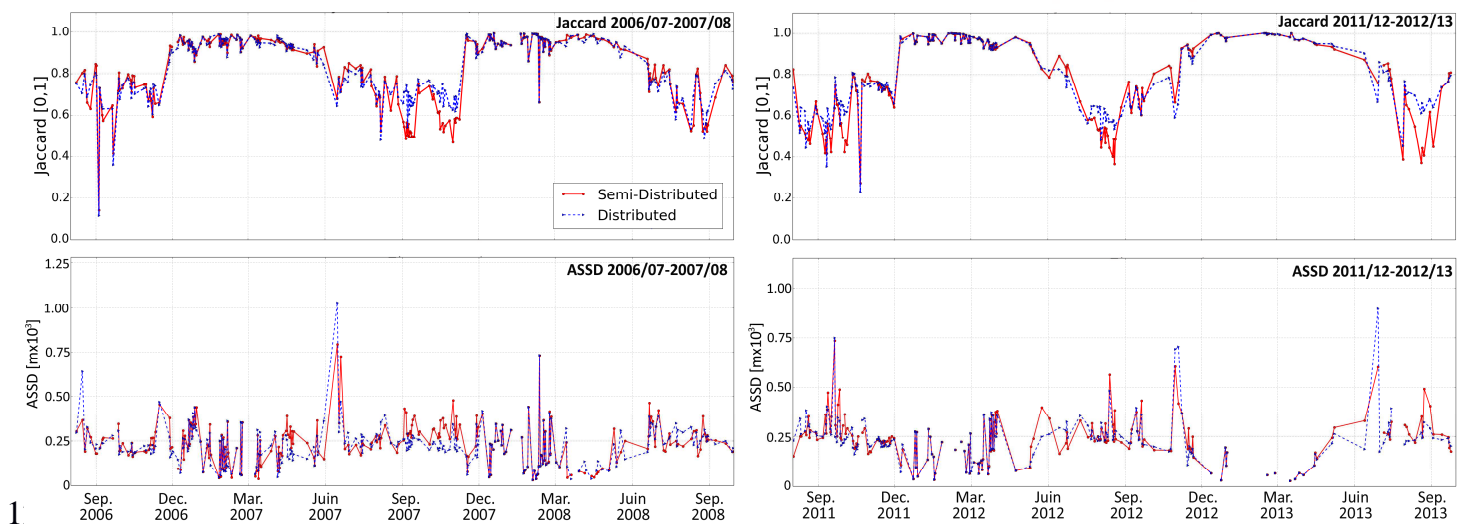

1213 Figure 9: Jaccard index and ASSD values for low level (2006-07 and 2007-08) and

1214 high level (2011-12 and 2012-13) snow accumulation seasons. 
The Cryosphere Discuss., https://doi.org/10.5194/tc-2017-184

Manuscript under review for journal The Cryosphere

Discussion started: 27 September 2017

(c) Author(s) 2017. CC BY 4.0 License.
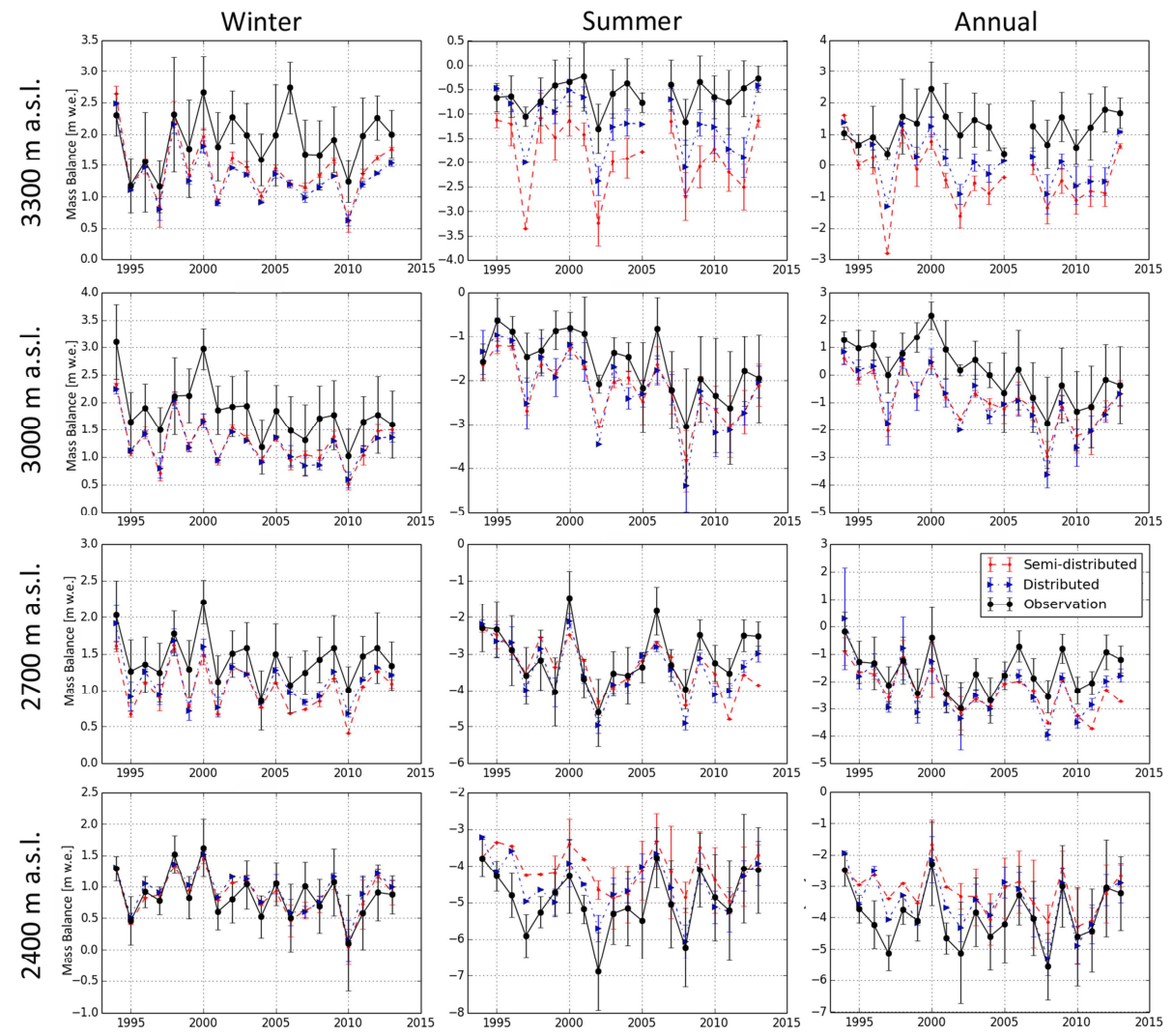

Figure 10: Temporal evolution of the observed and simulated (semi-distributed and distributed) SMB for the Argentière glacier for the four 300-m elevation bands for the period 1994-2013. The points show the average observation and simulation values for the same measurement locations, and the vertical bars show the standard deviations for those values. 
The Cryosphere Discuss., https://doi.org/10.5194/tc-2017-184

Manuscript under review for journal The Cryosphere

Discussion started: 27 September 2017

(c) Author(s) 2017. CC BY 4.0 License.
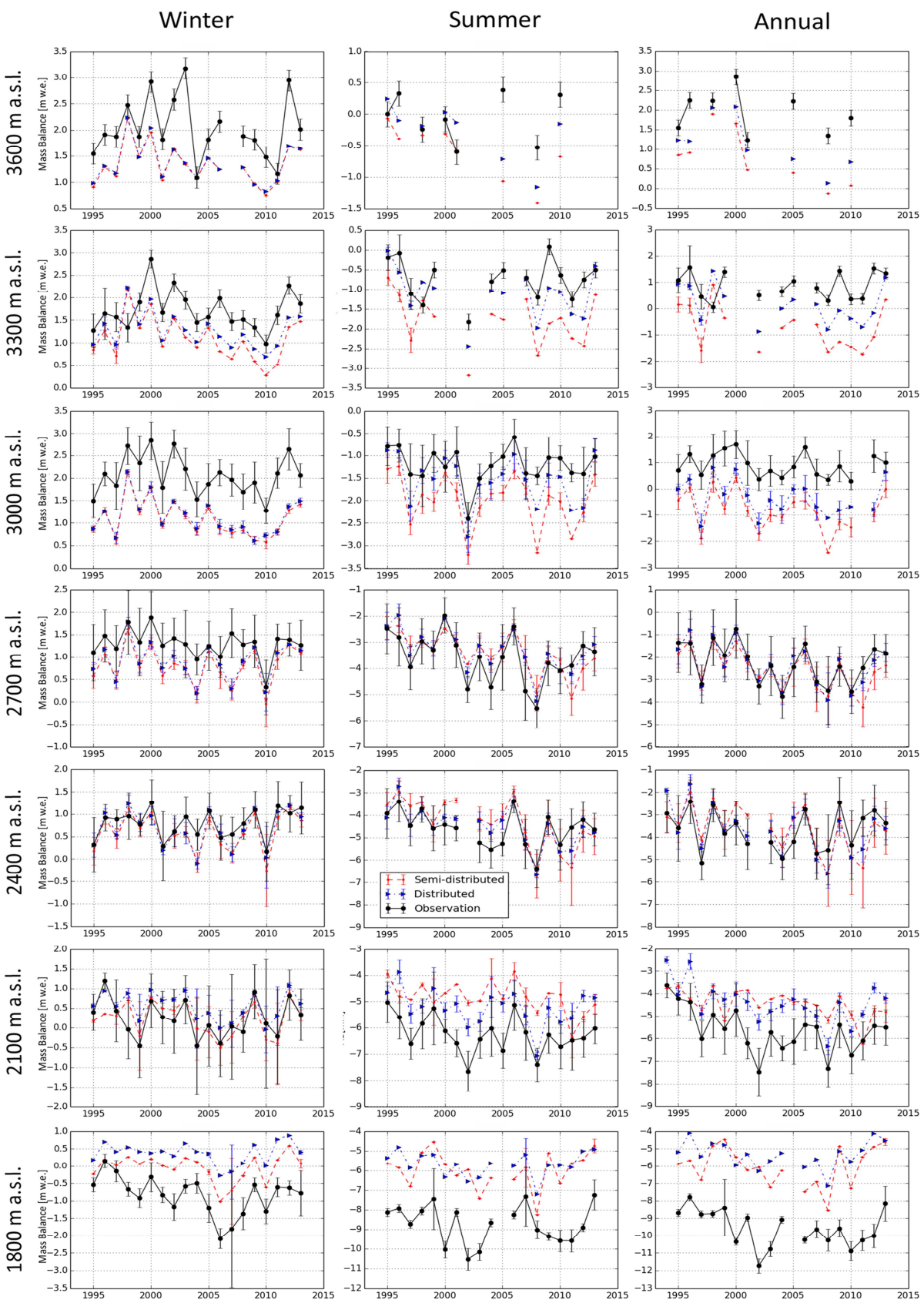

Figure 11: Temporal evolution of the observed and simulated (semi-distributed and distributed) SMB for the Mer de Glace glacier for the seven 300-m elevations bands for the period 1994-2013. The points show the average observation and simulation values for the same measurement locations, and the vertical bars show the standard deviations for those values. 
The Cryosphere Discuss., https://doi.org/10.5194/tc-2017-184

Manuscript under review for journal The Cryosphere

Discussion started: 27 September 2017

(c) Author(s) 2017. CC BY 4.0 License.
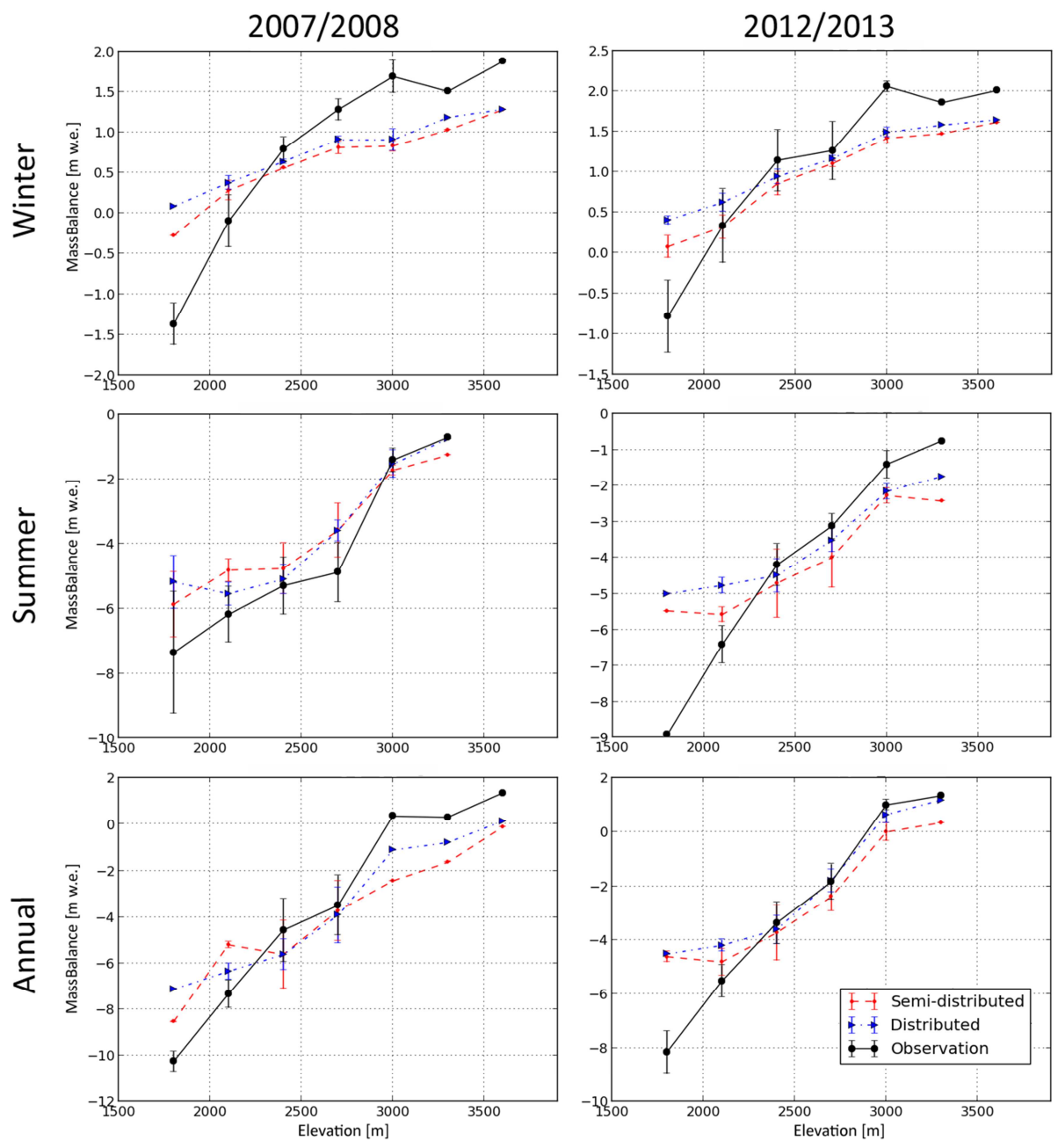

1229

1230

1231

1232

Figure 12: Altitudinal dependence of the observed and simulated (semi-distributed and distributed) SMB for two snow seasons (2007-08: low level snow accumulation; and 2012-13: high level snow accumulation) at the Mer de Glace glacier. 
The Cryosphere Discuss., https://doi.org/10.5194/tc-2017-184

Manuscript under review for journal The Cryosphere

Discussion started: 27 September 2017

(c) Author(s) 2017. CC BY 4.0 License.
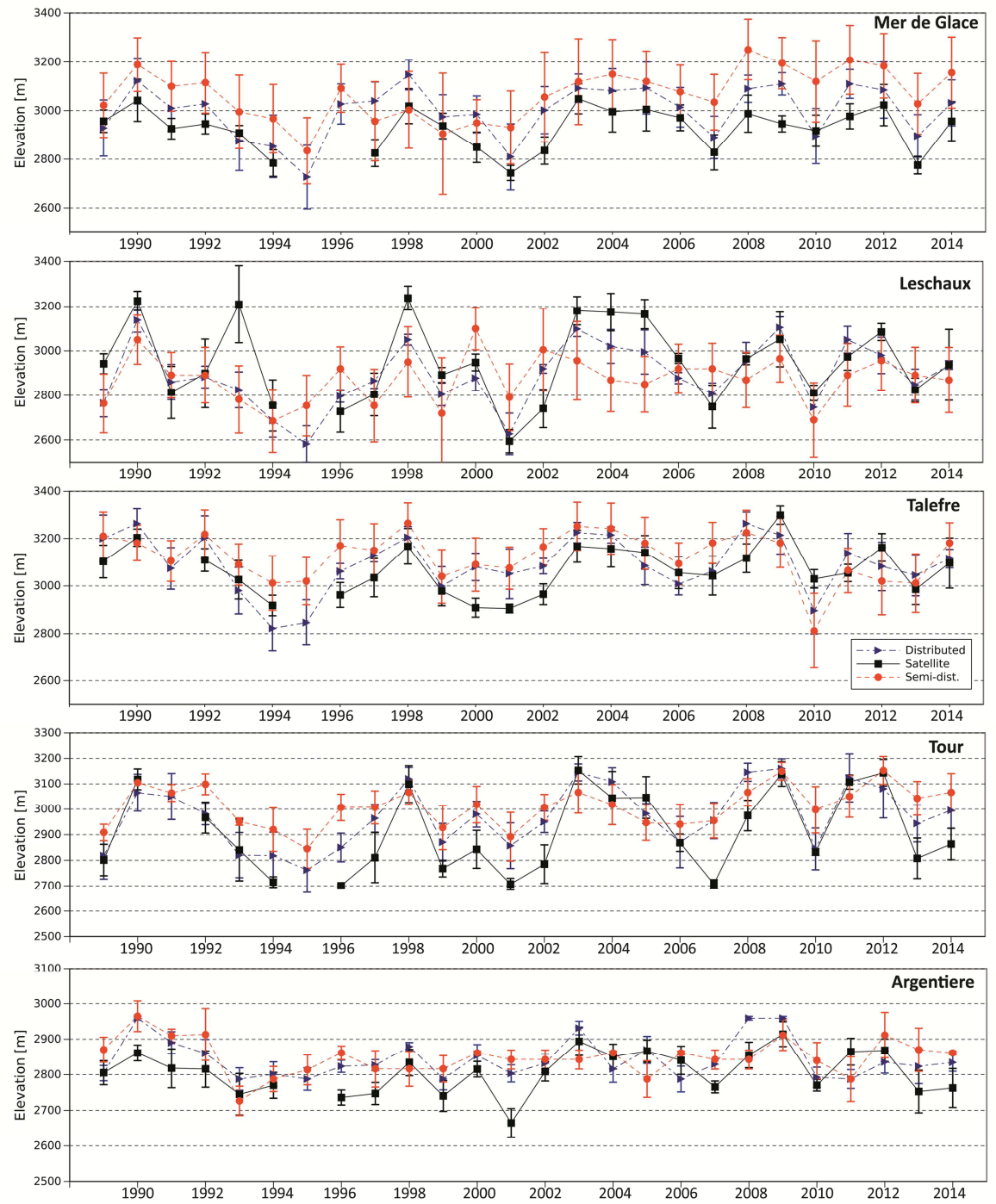

Figure 13: Observed and simulated evolution of the ELA for the five glaciers during 
The Cryosphere Discuss., https://doi.org/10.5194/tc-2017-184

Manuscript under review for journal The Cryosphere

Discussion started: 27 September 2017

(c) Author(s) 2017. CC BY 4.0 License.

1238

1239

1240

1241

1242

1243

1244

1245

1246

1247

1248

\begin{tabular}{ccccc} 
Observatory & $\begin{array}{l}\text { RMSE } \\
{[\mathbf{c m}]}\end{array}$ & Bias $[\mathbf{c m}]$ & Period & Num. Obs. \\
\hline Chamonix & 23.3 & 12.1 & $1983-2015$ & 6704 \\
Le Tour & 29.6 & 13.0 & $1985-2015$ & 6323 \\
$\begin{array}{c}\text { Nivose Aiguilles } \\
\text { Rouges }\end{array}$ & 66.6 & 49.4 & $1983-2015$ & 5902 \\
$\begin{array}{c}\text { La Flegere } \\
\text { Lognan }\end{array}$ & 45.0 & -19.1 & $2003-2015$ & 1231 \\
& 20.8 & 1.9 & $1994-2015$ & 5964
\end{tabular}

Table 1: Error statistics (bias and RMSE) between simulated and in situ snow depth observations for the five meteorological stations in the study area for periods for which observations were available. The locations of the stations are shown in Figure 1.

\begin{tabular}{ccccc}
\multicolumn{2}{c}{ Threshold } & R2 & RMSE[cm] & MAE \\
SCA [0,1] & SD [m] & & & \\
\hline \multirow{3}{*}{$\mathbf{0 . 3 5}$} & 0.1 & 0.821 & 12.64 & 8.36 \\
& $\mathbf{0 . 1 5}$ & $\mathbf{0 . 8 2 8}$ & $\mathbf{1 2 . 5 1}$ & $\mathbf{8 . 2 4}$ \\
& 0.2 & 0.815 & 12.86 & 8.54 \\
\hline
\end{tabular}

Table 2: UWS performance for various snow thicknesses selected as thresholds for the 2008-09 and 2009-10 snow seasons. Bold values indicate the selected snow depth threshold.

\begin{tabular}{ccccc} 
Period & Approach & $\mathbf{R}^{\mathbf{2}}$ & MAE & RMSE \\
\hline $\begin{array}{c}\text { Entire period } \\
\text { (2001-2015) }\end{array}$ & $\begin{array}{c}\text { Semi- } \\
\text { distributed }\end{array}$ & 0.815 & 10.47 & 15.28 \\
\cline { 2 - 4 } $2006-07$ to \\
$2007-08$ & $\begin{array}{c}\text { Semi- } \\
\text { distributed }\end{array}$ & 0.822 & 8.35 & 12.64 \\
\hline $\begin{array}{c}\text { Distributed } \\
2011-12 \text { to }\end{array}$ & $\begin{array}{c}\text { Semi- } \\
\text { distributed }\end{array}$ & 0.744 & 10.756 & 16.903 \\
\hline & $\begin{array}{c}\text { Distributed } \\
\text { 2012-13 }\end{array}$ & 0.881 & 11.56 & 14.82 \\
\hline
\end{tabular}

Table 3: RMSE, MAE and $\mathrm{R}^{2}$ values for the observed and simulated SCA (based on the distributed and semi-distributed approaches) for various time periods for the entire study area. 
The Cryosphere Discuss., https://doi.org/10.5194/tc-2017-184

Manuscript under review for journal The Cryosphere

Discussion started: 27 September 2017

(c) Author(s) 2017. CC BY 4.0 License.

\begin{tabular}{|c|c|c|c|c|}
\hline Period & Approach & $\mathbf{R}^{2}$ & MAE & RMSE \\
\hline \multirow{2}{*}{$\begin{array}{l}\text { Entire period } \\
(2001-2015)\end{array}$} & $\begin{array}{c}\text { Semi- } \\
\text { distributed }\end{array}$ & 0.71 & 10.12 & 16.04 \\
\hline & Distributed & 0.72 & 7.60 & 12.84 \\
\hline \multirow{2}{*}{$\begin{array}{l}2006-07 \text { to } \\
2007-08\end{array}$} & $\begin{array}{c}\text { Semi- } \\
\text { distributed }\end{array}$ & 0.58 & 11.26 & 18.36 \\
\hline & Distributed & 0.59 & 8.61 & 15.62 \\
\hline \multirow{2}{*}{$\begin{array}{l}2011-12 \text { to } \\
2012-13\end{array}$} & $\begin{array}{c}\text { Semi- } \\
\text { distributed }\end{array}$ & 0.82 & 11.30 & 16.38 \\
\hline & Distributed & 0.84 & 7.79 & 11.69 \\
\hline
\end{tabular}

Table 4: RMSE, MAE and $\mathrm{R}^{2}$ values for the observed and simulated SCA (based on the distributed and semi-distributed approaches) for various time periods for those parts of the study area having a northern aspect $(\mathrm{N}, \mathrm{NE}, \mathrm{NW})$.

\begin{tabular}{ccccc} 
Period & Approach & $\mathbf{R}^{2}$ & MAE & RMSE \\
\hline $\begin{array}{c}\text { Entire period } \\
\text { (2001-2015) }\end{array}$ & $\begin{array}{c}\text { Semi- } \\
\text { distributed }\end{array}$ & 0.851 & 10.23 & 14.99 \\
& Distributed & 0.856 & 9.89 & 14.21 \\
\hline $\begin{array}{c}\text { Semi- } \\
2006-07-08\end{array}$ & $\begin{array}{c}\text { distributed } \\
\text { Distributed }\end{array}$ & 0.815 & 10.34 & 16.48 \\
\hline $2011-12$ to & $\begin{array}{c}\text { Semi- } \\
\text { distributed }\end{array}$ & 0.902 & 10.98 & 16.21 \\
\hline & Distributed & 0.905 & 8.25 & 11.81
\end{tabular}

Table 5: RMSE, MAE and $\mathrm{R}^{2}$ values for the observed and simulated SCA (based on the distributed and semi-distributed approaches) for various time periods for those parts of the study area having a southern aspect (S, SE, SW). 
The Cryosphere Discuss., https://doi.org/10.5194/tc-2017-184

Manuscript under review for journal The Cryosphere

Discussion started: 27 September 2017

(c) Author(s) 2017. CC BY 4.0 License.

\begin{tabular}{|c|c|c|c|}
\hline Period & Approach & Jaccard & ASSD \\
\hline \multirow{2}{*}{$\begin{array}{l}\text { Entire period } \\
(2001-2015)\end{array}$} & $\begin{array}{c}\text { Semi- } \\
\text { distributed }\end{array}$ & 0.817 & 0.912 \\
\hline & Distributed & 0.832 & 0.975 \\
\hline \multirow{2}{*}{$\begin{array}{c}2006-07 \text { to } \\
2007-08\end{array}$} & $\begin{array}{c}\text { Semi- } \\
\text { distributed }\end{array}$ & 0.783 & 0.920 \\
\hline & Distributed & 0.801 & 0.952 \\
\hline \multirow{2}{*}{$\begin{array}{c}2011-12 \text { to } \\
2012-13\end{array}$} & $\begin{array}{c}\text { Semi- } \\
\text { distributed }\end{array}$ & 0.826 & 0.897 \\
\hline & Distributed & 0.836 & 0.952 \\
\hline
\end{tabular}

1263

1264

1265

1266

1267

Table 6: Average values of the Jaccard index and ASSD values for each simulation approach for various time periods.

\begin{tabular}{|c|c|c|c|c|c|}
\hline \multirow[t]{2}{*}{ Period } & \multirow[t]{2}{*}{ Approach } & \multicolumn{2}{|c|}{ Jaccard Index } & \multicolumn{2}{|c|}{ ASSD } \\
\hline & & JFM & MJJ & JFM & MJJ \\
\hline \multirow[t]{2}{*}{ 2006-07 } & $\begin{array}{c}\text { Semi- } \\
\text { distributed }\end{array}$ & 0.9535 & 0.802 & 0.687 & 1.152 \\
\hline & Distributed & 0.9557 & 0.823 & 0.704 & 1.104 \\
\hline \multirow[t]{2}{*}{ 2007-08 } & $\begin{array}{c}\text { Semi- } \\
\text { distributed }\end{array}$ & 0.950 & 0.793 & 0.717 & 1.062 \\
\hline & Distributed & 0.951 & 0.809 & 0.724 & 1.043 \\
\hline \multirow[t]{2}{*}{$2011-12$} & $\begin{array}{c}\text { Semi- } \\
\text { distributed }\end{array}$ & 0.968 & 0.756 & 0.711 & 0.983 \\
\hline & Distributed & 0.967 & 0.754 & 0.734 & 0.994 \\
\hline \multirow[t]{2}{*}{$12012-13$} & $\begin{array}{c}\text { Semi- } \\
\text { distributed }\end{array}$ & 0.980 & 0.790 & 0.199 & 1.271 \\
\hline & Distributed & 0.990 & 0.799 & 0.198 & 1.250 \\
\hline
\end{tabular}

Table 7: Average values of the Jaccard index and ASSD for each simulation approach for the maximum (JFM) and minimum (MJJ) snow accumulation periods. 
The Cryosphere Discuss., https://doi.org/10.5194/tc-2017-184

Manuscript under review for journal The Cryosphere

Discussion started: 27 September 2017

(c) Author(s) 2017. CC BY 4.0 License.

\begin{tabular}{|c|c|c|c|c|c|c|c|}
\hline Glacier & Period & Approach & RMSE & MAE & $\mathbf{R 2}$ & slope & Intersect \\
\hline \multirow{6}{*}{ Arg } & \multirow[t]{2}{*}{ WSMB } & $\begin{array}{c}\text { Semi- } \\
\text { distributed }\end{array}$ & 0.53 & 0.42 & 0.537 & 0.52 & 0.33 \\
\hline & & Distributed & 0.52 & 0.40 & 0.51 & 0.458 & 0.467 \\
\hline & \multirow[t]{2}{*}{ SSMB } & $\begin{array}{c}\text { Semi- } \\
\text { distributed }\end{array}$ & 0.96 & 0.78 & 0.72 & 0.56 & -1.47 \\
\hline & & Distributed & 0.76 & 0.61 & 0.84 & 0.737 & -1.04 \\
\hline & \multirow[t]{2}{*}{ ASMB } & $\begin{array}{c}\text { Semi- } \\
\text { distributed }\end{array}$ & 1.21 & 0.99 & 0.71 & 0.55 & -1.22 \\
\hline & & Distributed & 1.05 & 0.85 & 0.78 & 0.679 & -1.02 \\
\hline \multirow{6}{*}{ Mdg } & \multirow[t]{2}{*}{ WSMB } & $\begin{array}{c}\text { Semi- } \\
\text { distributed }\end{array}$ & 0.72 & 0.56 & 0.64 & 0.53 & 0.093 \\
\hline & & Distributed & 1.57 & 1.15 & 0.83 & 0.43 & 0.37 \\
\hline & \multirow[t]{2}{*}{ SSMB } & $\begin{array}{c}\text { Semi- } \\
\text { distributed }\end{array}$ & 1.46 & 1.17 & 0.75 & 0.55 & -1.33 \\
\hline & & Distributed & 1.19 & 0.86 & 0.86 & 0.67 & -0.94 \\
\hline & \multirow[t]{2}{*}{ ASMB } & $\begin{array}{c}\text { Semi- } \\
\text { distributed }\end{array}$ & 1.72 & 1.33 & 0.75 & 0.52 & -1.45 \\
\hline & & Distributed & 1.57 & 1.15 & 0.83 & 0.587 & -1.03 \\
\hline
\end{tabular}

1278

1279

1280

1281

Table 8: RMSE, MAE, $\mathrm{R}^{2}$ values for the slope and intersection in linear adjustments between the observed and simulated SMB for Mer de Glace (Mdg) and Argentière (Arg) glaciers. 
The Cryosphere Discuss., https://doi.org/10.5194/tc-2017-184

Manuscript under review for journal The Cryosphere

Discussion started: 27 September 2017

(c) Author(s) 2017. CC BY 4.0 License.

\begin{tabular}{|c|c|c|c|c|c|}
\hline Glacier & Approach & Avg Dif & $\begin{array}{l}\text { Std. Dev } \\
\text { (Differences) }\end{array}$ & Slope & $\mathbf{R 2}$ \\
\hline \multirow[t]{2}{*}{ Mdg } & $\begin{array}{c}\text { Semi- } \\
\text { distributed }\end{array}$ & 155.11 & 69.62 & 0.715 & 0.420 \\
\hline & Distributed & 88.57 & 48.90 & 0.869 & 0.627 \\
\hline \multirow[t]{2}{*}{ Les } & $\begin{array}{c}\text { Semi- } \\
\text { distributed }\end{array}$ & 158.34 & 101.84 & 0.188 & 0.102 \\
\hline & Distributed & 110.73 & 109.67 & 0.560 & 0.586 \\
\hline \multirow[t]{2}{*}{ Tal } & $\begin{array}{c}\text { Semi- } \\
\text { distributed }\end{array}$ & 105.14 & 59.25 & 0.4936 & 0.2336 \\
\hline & Distributed & 80.12 & 41.87 & 0.766 & 0.476 \\
\hline \multirow[t]{2}{*}{ Tour } & $\begin{array}{c}\text { Semi- } \\
\text { distributed }\end{array}$ & 105.14 & 59.25 & 0.339 & 0.528 \\
\hline & Distributed & 84.33 & 68.71 & 0.625 & 0.715 \\
\hline \multirow[t]{2}{*}{ Arg } & $\begin{array}{c}\text { Semi- } \\
\text { distributed }\end{array}$ & 63.89 & 42.87 & 0.270 & 0.103 \\
\hline & Distributed & 54.52 & 31.85 & 0.578 & 0.381 \\
\hline
\end{tabular}

1283 Table 9: Average differences, standard deviations, slope of the linear adjustment, and 1284 R2 values for the observed and simulated ELA for Mer de Glace (Mdg), Leschaux 1285 (Les), Talefre (Tal), Tour and Argntière (Arg) glaciers. 